\title{
THE POLICY OF FOREIGN PORTOFOLIO INVESTMENT LIBERALIZATION AND ITS IMPLICATIONS TOWARD THE NATIONAL BANKING POLICY ON GIVING THE CREDIT TO THE SMALL AND MEDIUM ENTERPRISES
}

\author{
Oleh: Sugeng Ribowo
}

\begin{abstract}
Foreign Portofolio Investment is one of the parts of foreign investment policy, its existence has the important role to the economic development of a country, especially to the developing countries to prevent the deficit of a country. Indonesia is one of developing countries that has implemented the policy rapidly by liberating foreign portofolio investment. This makes the foreign fund flood Indonesia without any control. Its legally caused legislation product regulating the kinds of this investment subtancially do not regulate legal precision between two countries. Therefore, it gives overborrowing impacts that have to be guaranted by a country in a certain time. Its different from other developing countries determined foreign portofolio investment with the strong control and given tax disincentive to the investors, such as China, Corea, Thailand and others.

The behavior of this policy, is appereant and it cannot be separate from foreign influence that suggested by International Monetary Fund (IMF) and World Bank (WB) as a financial international institution with the basic financial globalization. Financial globalization, directly and indirectly has supported the government policy that is very kind to the foreign intervention. Its evidenced by the dominated legalize by the ownership of foreign stock in foreign right corporation or financial institution (banking) that has implicitly through laws. Therefore, foreign portofolio investment has caused the magnetic strength, especially banking institution to get the traget of big gain by buying and selling it to foreigner than distributing of credit to the small and medium enterprises.

This phenomenon, implicates to the change to the policy in the banking sector, banking experienced shifting of vital function that as to be able to allocate the fund source to the society efficienly and effectivetely. The shifting of vital banking function, from traditional activity to the non-traditional activity is caused by the complicated problems like institution, regulation, and globalization, especially financial globalization. Therefore, the strength of the state about political economy is the main solution to solve these problems.

This research, will be analyzed comprehensively about the Policy of Foreign Portofolio Investment Liberalization and its Implications toward the National Banking Policy on Giving the Credit to the Small and Medium Enterprises. Beside, this research will also be explained the relevant policy to solve the vital functions of banking as intermediation institution to the small and medium enterprises, its influence can be hoped to the financial stability and economic development sustainability.
\end{abstract}

Key words: liberalization, foreign portofolio investment, financial globalization, political economy, national banking. 


\section{A. Pendahuluan}

\section{Latar Belakang Masalah}

Indonesia sebagai salah satu negara berkembang, jauh lebih awal telah meliberalisasi kebijakan investasi asingnya khususnya pada jenis investasi langsung (foreign direct investment) ${ }^{1}$ pada tahun 1990-an. Walaupun, pada dasarnya Indonesia sebelumnya menganut strategi investasi terbuka pada pertengahan 1970an, namun sejatinya Indonesia tetap mengontrol sirkulasi investasi asing. ${ }^{2} \mathrm{Di}$ samping itu, dalam jenis investasi tidak langsungnya (foreign portofolio investment) Indonesia secara aklamatif tidak langsung melakukan liberalisasi pada investasi jenis ini, walaupun banyak dari negara-negara berkembang di dunia telah meliberalisasi kebijakan investasi ini pada sekitar tahun 1980-an. ${ }^{3}$

Investasi portofolio adalah pembelian yang dilakukan, baik oleh individu maupun korporasi, produk keuangan, seperti: saham, obligasi, surat berharga, reksadana (mutual funds), dan lain-lain, dengan harapan akan mendapatkan keuntungan di masa yang akan datang. ${ }^{4}$ Investasi portofolio dapat dilakukan di dalam negeri

* Manager Bank Jawa Barat Syari'ah (BJBS) KCP. Cibinong

1 Foreign Direct Investment merupakan investasi yang dilakukan swasta asing ke suatu negara. Bentuknya dapat berupa cabang perusahaan multinasional, anak perusahaan multinasional, lisensi, joint ventura.

2 Khoiriati, Siti D., 'The Political Economy of Development in Indonesia and Japan', The Center of Japanese Studies University of Indonesia, Jakarta, 2008.

3 Parthapratim Pal, Foreign Portofolio Investment in Indian Equity Market: Has Economy Benefited?, Economic and Political Weekly, Vol. 33 No. 11 (January 1998), diakses di http://www.jstor.org/stable/4406523 pada tanggal 06 September 2010.

4 http://www.investorwords.com/2599/investmenthtml, diakses pada jam 08.15 pada tanggal 07 Oktober 2010 . (domestik portofolio investment - DPI) ataupun di luar negeri (foreign portofolio investment FPI). Pada dua dekade belakangan ini investasi portofolio, terutama investasi portofolio luar negeri berkembang sangat cepat, seiring dengan berkembangnya infrastruktur teknologi dan internet secara dramatis.

Di Amerika Serikat sejak tahun 1990 jumlah investasi portofolio luar negeri yang dilakukan individu sudah melampaui jumlah investasi langsung luar negeri (foreign direct investment) yang dilakukan oleh korporasi. Demikian juga, total penghasilan wajib pajak Amerika Serikat yang melakukan investasi portofolio luar negeri sudah melampaui penghasilan mereka dari investasi langsung luar negeri. Investasi portofolio bisa mendatangkan keuntungan bisa juga mendatangkan kerugian. Secara fiskal jenis keuntungan atau penghasilan yang bisa diterima atau diperoleh dan jenis kerugian atau beban yang diderita dari investasi portofolio luar negeri ialah keuntungan atau kerugian dari penjualan sekuritas (saham, obligasi, reksadana, dan lain-lain), keuntungan/kerugian dari selisih kurs, dan juga penghasilan berupa dividen, penghasilan/beban bunga, serta beban lainnya, seperti fee broker, beban bank, dan lain-lain.

Kebutuhan akan investasi portofolio pada awalnya dibentuk berdasarkan kebutuhan perkembangan ekonomi nasional suatu negara. Dalam perkembangan ekonomi tersebut, dibutuhkan mobilisasi dana dari masyarakat untuk pembiayaan pembangunan. Dalam konteks Indonesia, dalam hal kebijaksanaan pembangunan nasional melalui investasi jenis ini Indonesia menggunakan pola top bottom process. Hal ini berbeda dengan 
negara-negara kapitalis-liberal yang menggunakan sistem bottom up process. ${ }^{5}$

Dalam sistem top bottom process, investasi pada jenis portofolio (tidak langsung) masih bersifat tertutup, artinya masih dalam bentuk mobilisasi dana yang bersumber dari masyarakat internal sendiri.

Proses investasi asing di Indonesia mengalami pasang surut yang signifikan. Hal ini disebabkan karena kondisi stabilitas politik yang berubah-ubah, sehingga menyebabkan Indonesia sangat membutuhkan arus modal asing (capital inflow), dari instrumen investasi tidak langsung asing (foreign portofolio investment).

Dalam kondisi seperti itu, guna membiayai defisit pembangunan, maka pada era kepemimpinan President Megawati Soekarno Putri, Indonesia melakukan liberalisasi investasi portofolio khususnya obligasi negara dengan mengeluarkan Undang-Undang Surat Utang Negara (SUN) Nomor 24 Tahun 2002 yang selanjutnya diikuti kebijakan pengeluaran jenis instrumen portofolio lainnya hingga pada kepemimpinan era Presiden Susilo Bambang Yudhoyono. Kebijakan-kebijakan liberalisasi portofolio tersebut di antaranya adalah ORI (Obligasi Ritel Indonesia) tahun 2006, UndangUndang Nomor 19 Tahun 2008 tentang Surat Berharga Negara Syariah (SBSN), Surat Perbendaharaan Negara (SPN) 2002, dan lain sebagainya.

Sebagaimana teori-teori pembangunan, pembangunan ekonomi sangat ditopang oleh penguatan sektor riil (foreign direct investment). Pada tataran penguatan sektor riil, perekonomian Indonesia yang berkembang hingga saat ini tidak dapat

Jusuf Anwar, Pasar Modal Sebagai Sarana Pembiayaan dan Investasi, Bandung: PT. Alumni, 2005, hlm. 53. dipisahkan dari keberadaan dan dukungan sejumlah besar Small and Medium Enterprises atau Usaha Mikro Kecil Menengah (UMKM). Data-data statistik menunjukkan, UMKM di Indonesia mencapai $99,8 \%$ dari total perusahaan, sementara sumbangannya terhadap ekonomi mencapai $63,4 \%$ dari total GDP. Dalam penyerapan tenaga kerja, UMKM menyerap tenaga kerja $83 \%$ dari total pekerja ${ }^{6}$.

Dibalik perannya yang begitu signifikan dalam perekonomian, kenyataan ini tidak dibarengi perhatian yang besar oleh pemerintah. Dalam hal ini, pemerintah Indonesia kurang menaruh perhatian yang serius untuk mengembangkan UMKM sebagai bagian penting dari perekonomian Indonesia. Hal ini ditunjukkan, pasca kemerdekaan Indonesia tahun 1945, UMKM tidak mendapat perhatian penting pemerintah. Salah satu indikasi faktual, ditunjukkan dengan tidak adanya Peraturan Pemerintah (PP) setingkat Undang-Undang yang mengatur UMKM.

Perhatian yang serius terhadap UMKM baru ditunjukkan pemerintah setelah memasuki dekade 1980-an, ketika pendapatan negara dari ekspor minyak dan gas mulai menurun secara drastis. Pada waktu itu, pemerintah mulai mendorong UMKM untuk meningkatkan produktivitas mereka dan mengembangkan riset pasar untuk menjangkau pasar internasional. Namun demikian, kebijakan tersebut ternyata kurang berhasil mengingat kompetisi di pasar internasional sudah sangat ketat, sementara UMKM di Indonesia belum terkondisikan untuk bersaing di pasar internasional. Kebanyakan UMKM di Indonesia masih sangat lemah, baik dari sisi permodalan,

6 Ibid. 
manajemen, maupun daya saingnya dengan produk dari negara lain.

Dengan dikeluarkannya kebijakan liberalisasi sebagaimana dijelaskan di atas, maka lembaga yang sangat berhubungan dengan penyehatan UMKM, yaitu bank sebagai lembaga intermediasi bagi UMKM cenderung memperbesar porsinya terhadap instrumen-instrumen yang telah diliberalisasi tersebut, sehingga liberalisasi melalui undang-undang ini benar-benar telah membuat instrumen foreign portofolio investment khususnya obligasi negara menjadi serbuan investor asing, sehingga membanjiri Indonesia dari tahun ke tahun dan kadang melebihi kuantitasnya daripada instrumen foreign direct investment.

Seiring dengan perjalanan waktu, liberalisasi terhadap foreign portofolio investment, telah mengakibatkan sektor perbankan mengalami transformasi dan perubahan yang mempengaruhi aktivitas bisnis intinya, yang seharusnya menjadi lembaga intermediasi yang berperan aktif mendukung kegiatan bisnis yang produktif dengan memberikan pinjaman modal kerja atau investasi. Atau dengan kata lain, aktivitas perbankan telah mengalami pergeseran dari aktivitas bisnis yang "tradisional" (memberikan pinjaman modal kerja dan investasi) ke arah aktivitas bisnis yang "non-tradisional" (fee based income, dealer transaksi derivatif, ${ }^{7}$ dan lain-lain). Tentu saja keadaan ini dipicu oleh beberapa hal yang kompleks, menyangkut keadaan

\footnotetext{
Terminologi transaksi derivative berdasarkan UU Bank Indonesia No.7/31/PBI/2005 adalah "Dervative Transactions are transctions based on a contract or agreement for payment in which the value is a derivative of the value of underlying instrument, such as interest rates, exchange rates, commodities, equity and indices, wether accompanied by or not accompanied by notional amount or instruments, but not including credit derivative transactions. "Sumber: http://www.bi.go.id
}

kompetisi pasar keuangan domestik, regulasi, kelembagaan, globalisasi ekonomi dan keuangan maupun kemajuan teknologi. ${ }^{8}$

Munculnya pergeseran tersebut bisa jadi merupakan implikasi dari kebijakankebijakan negara yang dipolitisasi oleh sekelompok aktor yang secara substansial seharusnya justru bertanggungjawab atas pembangunan dan perngembangan UMKM) di Indonesia. Dunia perbankan dan Kementrian Koperasi dan UKM merupakan manifestasi institusi yang bertanggungjawab atas kemajuan UMKM di Indonesia. Dalam tataran kebijakan formal, baik Kementrian Koperasi dan UKM maupun Perbankan memiliki pedoman buku putih yang sangat baik. Namun, dalam tataran implementasi belum tentu sejalan.

Kementrian Koperasi dan UKM sebagai institusi resmi pemerintah sejak dibentuknya institusi ini di era reformasi, berdasarkan tugas pokok yang diembannnya, upaya memajukan UMKM secara holistik belum sepenuhnya dilakukan, sehingga terbukti aturan perundang-undangan tentang UMKM sangat lambat dibentuk dan mengalami tarik ulur yang alot di Dewan Perwakilan Rakyat (DPR) Republik Indonesia. Hal ini tentu saja berimbas terhadap kebijakan dunia perbankan nasional dalam upaya pemberian kredit UMKM.

\footnotetext{
8 Penurunan aktivitas perbankan tradisional telah terungkap oleh Frederich S. Mishkin dan Franklin R. Edwards dalam "The Decline of Traditional Banking: Implications for Stability and Regulatory policy." Dalam tulisannya, mereka mengamati pergeseran aktivitas perbankan di negara-negara industri besar, seperti US, Jepang, dan Eropa. Namun, mereka juga tidak memungkiri hal yang sama terjadi di negara-negara lainnya, termasuk negara berkembang.
} 
Keberadaan peraturan perundangundangan yang memihak sangat berperan signifikan dalam mendorong percepatan pembangunan atas sesuatu hal yang diundangkan, termasuk misalnya perkembangan UMKM. Hal serupa, misalnya telah dilakukan oleh Jepang melalui peraturan perundang-undangannya yang sangat pro secara action, yaitu Small and Medium Enterprises Basic Law tahun 1963 yang terbukti telah membawa perkembangan UMKM maju dengan pesatnya. Undang-undang ini telah memberikan ruang harmonisasi antara pusat dengan daerah, sehingga percepatan pertumbuhan dapat berjalan beriringan dengan baik. Lantas, apa sebenarnya yang membuat Indonesia enggan mengatur UMKM-nya secara holistik melalui peraturan perundang-undangan yang memihak sebagaimana negara-negara lain yang sejatinya industri manufakturnya telah jauh lebih maju daripada Indonesia, sehingga pemerintah Indonesia mengalami kegagalan (government failure) dalam mensejahterakan rakyatnya? Pada titik inilah penelitian ini hadir untuk mengupas apa sebetulnya hambatan politik dari fenomena-fenomena tersebut dan juga apa implikasi kebijakan liberalisasi foreign portofolio investment terhadap kebijakan perbankan, sehingga fungsi perbankan menjadi disintermediasi, khususnya pada kurun waktu pemerintahan Presiden Megawati Soekarno Putri dan Susilo Bambang Yudhoyono, serta alternatif kebijakan apa yang relevan pada permasalahan yang dikemukakan.

\section{Kerangka Konseptual}

Dalam upaya memahami kebijakan liberalisasi foreign portofolio investment dan implikasinya terhadap kebijakan perbankan nasional dalam pemberian kredit bagi pengembangan UMKM, penelitian ini akan menggunakan kerangka konseptual ekonomi politik yang dikemukakan Coporaso dan Levine dan globalisasi keuangan yang dikemukakan Schumekler.

\section{Ekonomi Politik}

Dalam beberapa hal penting, kehidupan kita adalah tentang ekonomi politik. Untuk bertahan hidup, kita perlu makan. Sebagian besar dari manusia mendapatkan kebutuhan yang diperlukan dari pasar, membayarnya dengan uang yang kita peroleh. Kita tidak dapat membeli apapun tanpa uang, untuk mendapatkan barang-barang kita membutuhkan kekayaan. Pasar modern didasarkan pada aturan-aturan politik. Regulasi dan aturan politik menyatakan kerangka kerja yang dengannya pasar berfungsi. Pada saat bersamaan kekuatan ekonomi merupakan basis bagi kekuatan politik. Jika ekonomi adalah tentang pencapaian kekayaan maka politik tentang pencapaian kekuatan, keduanya berinteraksi dalam cara yang rumit.

Terlepas dari sejarah teori ekonomi politik yang rumit tersebut, pendekatan ekonomi politik sendiri secara definitif dimaknai sebagai interrelasi di antara aspek, proses, dan institusi politik dengan kegiatan ekonomi (produksi, investasi, penciptaan harga, perdagangan, konsumsi, dan lain sebagainya). ${ }^{9}$ Mengacu pada definisi tersebut, pendekatan ekonomi politik mengaitkan seluruh penyelenggaraan politik, baik yang menyangkut aspek, proses, maupun kelembagaan dengan kegiatan ekonomi yang dilakukan oleh masyarakat maupun yang diintrodusir oleh pemerintah. Harus

9 Coporaso and Levine, Theories of Political Economy, Cambridge, Cambridge University Press, 1993, hlm. 31. 
juga dipahami bahwa pendekatan ini meletakkan bidang politik subordinat terhadap ekonomi. Artinya, instrumeninstrumen ekonomi seperti mekanisme pasar, harga, dan investasi dianalisis dengan mempergunakan setting sistem politik dimana kebijakan atau peristiwa ekonomi itu terjadi. Dengan kata lain, pendekatan ini melihat ekonomi sebagai cara untuk melakukan tindakan ( $a$ way of acting). Dengan demikian, tidak mungkin menggabungkan alat analisis ekonomi dan politik karena bisa sangat ambigu dan membingungkan. Sungguhpun begitu antara ekonomi dan politik dapat disandingkan dengan pertimbangan keduanya mempunyai proses yang sama. Setidaknya keduanya memiliki perhatian yang sama terhadap isu-isu sebagai berikut: mengorganisasi dan mengoordinasi kegiatan manusia, mengelola konflik, mengalokasikan beban dan keuntungan, dan menyediakan kepuasan bagi kebutuhan dan keinginan manusia. ${ }^{10}$ Berdasarkan pemahaman ini, pendekatan ekonomi politik mempertemukan antara bidang ekonomi dan politik dalam hal alokasi sumber daya ekonomi dan politik untuk dapat memenuhi kebutuhan masyarakat. Oleh karena itu, implementasi dari kebijakan ekonomi politik selalu mempertimbangkan struktur kekuasaan dan sosial yang hidup dalam masyarakat, khususnya target masyarakat yang menjadi sasaran kebijakan.

Secara definitif ilmu ekonomi selalu merujuk pada tiga konsep berikut: kalkulasi (calculation), penyediaan materi (material provisioning), dan meregulasi sendiri (self regulating). ${ }^{11}$ Konsep tersebut dapat

10 Barry Clark, Political Economy: A Compatitive Approach, Second Edition, Praeger.WesportConectitut.London, 1998, hlm. 6

11 Coporaso and Levine, op.cit., hlm. 21-30 dijabarkan sebagai berikut. Ujung dari analisis ekonomi selalu berupa mencari kalkulasi hasil yang paling efisien di antara keterbatasan pilihan yang tersedia (constrained choice). Di sini diandaikan semakin efisien hasil yang diperoleh, maka semakin bagus pilihan yang diambil. Setelah itu, kegiatan ekonomi selalu bertujuan untuk melakukan produksi (reproduksi) dan sirkulasi (distribusi). Dalam konteks ini, penyediaan material (barang/jasa) dalam kegiatan ekonomi selalu bersinggungan dengan desain struktur produksi. Terakhir, ekonomi beragumentasi bahwa pasar dapat mengatur dirinya sendiri. Pada titik inilah ekonomi dan politik (kelembagaan) itu terpisah.

Ilmu politik juga berjalan dengan tiga konsep baku, yakni politik sebagai pemerintah (government), otoritas yang mengalokasikan nilai (authoritative allocation of values), dan publik (public). ${ }^{12}$ Politik sebagai pemerintah jelas tugasnya untuk memberikan direksi dan mengeluarkan regulasi. Di sini, sifat pemerintah berupaya menyediakan panduan dan melakukan intervensi sehingga bertabrakan dengan sifat ekonomi yang mempercayai pasar bisa bekerja secara mandiri. Selanjutnya, politik juga mengalokasikan nilai-nilai. Konsep nilai dalam politik tidak setumpul nilai dalam ekonomi yang sering dimaknai sekedar efisiensi/laba. Dalam politik nilai itu bekerja berdasarkan norma-norma yang hidup dalam masyarakat, seperti perlunya pemerataan/keadilan pembangunan. Di sini, konsep keadilan mengungguli efisiensi bila yang terakhir ini dicapai dengan jalan menciptakan ketimpangan. Kemudian politik sebagai publik bermakna bahwa output dari politik merupakan urusan

12 Coporaso and Levine, op.cit., hlm. 7-15 
bersama (public concern), berbeda dengan ekonomi yang berkonotasi privat (private concern). Jadi, dengan deskripsi tersebut antara ekonomi dan politik memang memiliki asumsi yang berbeda, sehingga menggabungkan analisis ekonomi dan politik secara bersamaan merupakan upaya yang tidak akan pernah berhasil.

Dalam model kebijakan ekonomi sendiri setidaknya dikenal dua perspektif yang dipakai untuk menjelaskan proses pengambilan keputusan. ${ }^{13}$ Pertama, pendekatan yang berbasis pada maksimalisasi kesejahteraan konvensional (conventional welfare maximalization). Pendekatan ini berasumsi bahwa pemerintah (negara) bersifat otonom dan eksogen terhadap sistem ekonomi sehingga setiap kebijakan yang diciptakan berorientasi kepada kepentingan publik. Di sini pemerintah dianggap aktor yang serba tahu dan tidak memiliki kepentingan sendiri (self-interest). Kegagalan pasar dan efisiensi dalam alokasi sumber daya merupakan pusat dari pendekatan ini. Akibat adanya kegagalan pasar dan alokasi sumber daya tersebut, pemerintah diharapkan hadir melalui kebijakan untuk melakukan koreksi pasar sehingga kepentingan kesejahteraan rakyat/publik bisa dicapai. Pendekatan ini juga memasukkan model yang mempertimbangkan pemerintah sebagai agen yang memaksimalkan fungsi tujuan kesejahteraan publik, sehingga seringkali disebut dengan "fungsi preferensi politik" (political preference function). Pendeknya, pendekatan ini menganggap negara atau pemerintah sebagai aktor yang memiliki

13 Romina Pipitone, Lobbying: A New Approach for Agricultural Policies, CIRMET, Universita degli studi di Palermo, Italy, hlm. 3-4. nilai-nilai kebijakan untuk memakmurkan masyarakatnya.

Kedua, pendekatan yang berdasarkan pada asumsi ekonomi politik dan sering disebut dengan "ekonomi politik baru" (new political economy). Pendekatan ini menolak ide pendekatan pertama yang menempatkan pemerintah (negara) sebagai aktor yang "maha tahu" sehingga bisa mengatasi kegagalan pasar. Sebaliknya, pendekatan ini justru beragumentasi bahwa negara sendiri berpotensi mengalami kegagalan (government failure). Pendekatan ini mengalokasikan pada alokasi sumber daya publik dalam pasar politik (political market) dan menekankan pada perilaku mementingkan diri sendiri (self-interest-motivated) dari politisi, pemilih, kelompok penekan, dan birokrat. Secara jamak, dalam literatur, perilaku agen-agen tersebut diasumsikan rasional dan berusaha untuk memaksimalkan keuntungan pribadi melalui lobi, kesejahteraan pemilih, dan dukungan politik. Tentu saja, dalam posisi ini, tidak dibenarkan membiarkan negara menguasai perangkat kebijakan karena hal itu berpotensi menimbulkan mislokasi sumber daya ekonomi dan politik.

Dalam pendekatan ekonomi politik ini, setidaknya terdapat lima hal yang memperkuat pemakaiannya. Pertama, penggunaan kerangka kerja ekonomi politik berupaya untuk menerima eksistensi dan validitas dari perbedaan budaya politik, baik formal maupun informal. Kedua, analisis kebijakan akan memperkuat efektivitas sebuah rekomendasi karena mencegah pemikiran yang deterministik. Ketiga, analisis kebijakan mencegah pengambilan kesimpulan terhadap beberapa alternatif tindakan berdasarkan kepada perspektif waktu yang sempit. Keempat, analisis kebijakan yang berfokus ke negara 
berkembang tidak bisa mengadopsi secara penuh orientasi teoritis statis. Kelima, analisis kebijakan lebih mampu menjelaskan interaksi antar manusia. ${ }^{14}$

\section{Kebijakan liberalisasi foreign} portofolio investment, sebagai aktivitas ekonomi yang liberal, akan berakibat aktivitas ekonomi yang tidak terkontrol, apabila tidak diikuti dengan aktivitas politik yang kuat. Perbankan sebagai lembaga yang potensial melakukan aktivitas pembelian maupun penerbitan foreign portofolio investment sangat rentan terhadap aktivitas ekonomi yang tidak terkontrol, sehingga penyelewengan fungsi utama intermediasi dapat terabaikan tanpa aktivitas politik yang kuat. Aktivitas liberalisasi foreign portofolio investment berpengaruh terhadap fungsi vital/utama perbankan dalam pemberian kredit kepada UMKM.

Kebijakan pemerintah dalam pengembangan UMKM yang paling penting adalah dalam bidang bantuan finansial. Hal ini mengingat masalah finansial dalam masalah pemodalan atau pembiayaan merupakan salah satu masalah sulit yang dihadapi oleh para pelaku UMKM di Indonesia. Sebagian besar UMKM di Indonesia memenuhi kebutuhan pembiayaannya dengan mengandalkan uang pribadi yang berasal dari tabungan, pinjaman dari saudara atau teman, atau meminjam dari rentenir. Sumber-sumber pembiayaan tersebut umumnya tidak dapat diandalkan keberlangsungannya, di samping memberatkan. Sedangkan untuk menarik pinjaman dari institusi keuangan formal seperti bank, kebanyakan UMKM masih belum bisa memenuhi persyaratan

14 Donald Rotchild and Robert L. Curry Jr, Scarcty, Choice, and Public Policy in Middle Africa, London, University of California Press, 1978, hlm. 6-9. yang ditetapkan, khususnya dalam penyediaan jaminan (kolateral). Oleh karena, perlu ada campur tangan pemerintah secara politik guna membantu UMKM mengatasi kesulitan finansialnya.

Untuk memenuhi kebutuhan pembiayaannya, terutama untuk modal kerja, UMKM banyak menggantungkan pada bantuan pemerintah dan berbagai lembaga keuangan formal maupun nonformal seperti perbankan, non-perbankan, modal ventura, pelepas uang, dan dari pihak-pihak swasta lainnya.

Program pemberian kredit yang bersifat nasional bagi UMKM sudah dimulai sejak pemerintahan orde baru dengan berbagai kredit bersubsidi hingga era sekarang. Pada tahun 1973, pemerintah memperkenalkan dua jenis kredit, yaitu (1) Kredit Investasi Kecil (KIK) dan, (2) Kredit Modal Kerja Permanen (KMKP) kepada para pelaku UMKM. Program kredit ini disubsidi oleh Bank Indonesia dan penjaminan kredit dilakukan oleh PT Askrindo. Sebagai program nasional, program kredit bersubsidi ini didukung oleh sejumlah besar bank-bank milik pemerintah pusat (Bank BUMN) maupun bank milik pemerintah daerah, di samping juga bank-bank swasta. ${ }^{15}$

Namun, pada akhirnya program ini ternyata kurang berhasil, terutama dari sisi penjaminan kredit. Hal ini dikarenakan sulitnya akses untuk mendapatkan kredit serta tingginya bunga yang diberikan, sehinnga realisasi pemerintah melalui lembaga keuangan formal (perbankan) untuk mengembangkan UMKM mengalami perkembangan yang stagnan.

Arah kebijakan perbankan pada tahun

15 Khoiriati, Siti D." "The Political Economy of Development in Indonesia and Japan", The Center of Japanese Studies University of Indonesia, Jakarta, 2008, hlm. 179. 
2008 tetap ditekankan pada peningkatan peran bank sebagai lembaga intermidiasi. Sektor perbankan masih berperan sebagai penggerak utama pertumbuhan ekonomi di Indonesia. Oleh karena itu untuk mengoptimalkan peran intermediasi perbankan, selain menggalakan program sertifikasi, Bank Indonesia (BI) telah mengeluarkan berbagai kebijakan untuk mendorong pertumbuhan kredit. Demi merangsang perbankan nasional agar bisa menjalankan fungsi intermediasi secara lebih efektif, BI mengeluarkan beberapa paket kebijakan, antara lain: pada bulan Maret 2007 BI mengeluarkan Peraturan Bank Indonesia (PBI) Nomor 9/6/2007 mengenai Perubahan Ketentuan Kualitas Aktiva Bank umum. Perubahan tersebut mengenai penilaian kualitas yang tadinya berdasarkan kinerja keuangan, ketetapan membayar, dan prospek usaha, diubah menjadi hanya satu pilar, yaitu ketepatan pembayaran pokok dan bunga. ${ }^{16}$

Rendahnya akses pemberian kredit kepada UMKM, lebih dikarenakan perbankan lebih suka melakukan aktivitas bisnis (ekonomi) dalam rangka untuk memperoleh keuntungan yang lebih besar dan cepat melalui instrumen investasi portofolio. Karena itu, dalam mengatasi masalah bisnis (ekonomi) tersebut, maka yang dibutuhkan adalah pemerintah sebagai manajer yang kompeten (competent manajer). Jika tanpa syarat itu, maka tindakan ekonomi politik pemerintah akan berpotensi gagal atau menambah problem baru dan menimbulkan ketidakstabilan pada pasar secara keseluruhan.

Di sini intervensi pemerintah merupakan peluang yang bagus untuk

16 Miranda S. Gultom, "Optimalisasi Peran Intermidiasi Dan Konsolidasi Perbankan”, Info Bank, No. 346, Januari 2008. menciptakan stabilitas ekonomi, namun hal itu juga tidak mudah dijalankan karena kegiatan ekonomi merupakan multifaset yang sulit ditebak alirannya. Oleh karena itu, agar intervensi pemerintah tidak terjebak menjadi "kegagalan pemerintah", maka pemerintah yang kompeten sangat dibutuhkan. Peran pemerintah secara politik berperan besar dalam mengontrol dan mengendalikan kegiatan ekonomi yang berlangsung pada kebijakan-kebijakan yang menyangkut publik.

\section{Globalisasi Keuangan}

Peran yang minim oleh negara dalam kebijakan liberalisasi, akan mengakibatkan pergeseran fungsi vital perbankan ke arah yang lebih liberal, dalam arti bahwa sektor perbankan mengalami pergeseran aktivitas, dari yang sifatnya tradisional (pemberian kredit atau pinjaman) ke arah aktivitas yang sifatnya non-tradisional (fee based income, dealer maupun player dalam transaksi derivative dan off balance sheet, serta transaksi beresiko tinggi lainnya). Hal ini tentu saja akan menyebabkan instabilitas pada sistem keuangan domestik, dan perekonomian secara umum, karena dengan pergeseran peran sektor perbankan yang makin tidak terkendali akan meningkatkan keterbukaan resiko suatu negara terhadap terjadinya krisis keuangan yang berbiaya tinggi.

Di negara-negara berkembang, termasuk Indonesia, sektor perbankan merupakan sektor yang sangat vital dalam sistem keuangan. Sehingga dengan mandulnya peran sektor ini di sektor keuangan, maka pembangunan ekonomi secara umum akan makin terhambat (kemiskinan, pengangguran, serta disparitas pendapatan akan semakin tinggi).

Berdasarkan hasil empiris yang ditemukan oleh Mohanti, Schanabel, 
Garcia-Luna, ${ }^{17}$ bahwa perkembangan kredit di negara berkembang telah mengalami pergeseran ke arah kredit konsumtif dengan pertumbuhan yang sangat tinggi. Selanjutnya dalam penelitianya juga ditemukkan bahwa pertumbuhan aset di negara berkembang juga meningkat dalam pembelian sekuritas pemerintah (obligasi), khususnya untuk membiayai defisit anggaran pemerintah yang cukup besar di negara tersebut.

Keadaan ini tentu saja menimbulkan resiko dan ancaman stabilitas yang semakin meningkat bagi perbankan negara-negara berkembang, khususnya jika negara tersebut mengalami resesi atau kemunduran ekonomi yang menyebabkan pendapatan masyarakatnya menurun. Keadaan tersebut tentu akan semakin meningkatkan tingginya ketidakmampuan membayar atau default para nasabah terhadap kredit konsumsi yang dilakukannya. Hal ini merupakan pelajaran yang cukup penting, jika kita melihat permasalahan sub prime mortgage atau krisis kepemilikan rumah yang terjadi di Amerika Serikat akhir-akhir ini.

Permasalahan di sektor keuangan perbankan saat ini tidak terlepas dari pengaruh globalisasi keuangan, khususnya bagaimana liberalisasi pasar keuangan (pasar modal dan saham) dan inovasi teknologi telah banyak mempengaruhi perilaku dan aktivitas perbankan. Bahkan krisis keuangan dan perbankan yang terjadi di hampir sebagian negara di dunia, ${ }^{18}$ termasuk Indonesia, menunjukkan lemahnya kelembagaan dan regulasi

17 Bank of International Settlement, Pp. 28

18 Efek globalisasi keuangan terhadap krisis keuangan terjadi di beberapa Negara, antara lain: Asia dan Rusia 1997-1998, Brazil 1999, Ekuador 2000, Turki 2001, Argentina 2001 dan Uruguay 2002. keuangan dalam menghadapi tantangan globalisasi.

Secara ringkas, keuntungan globalisasi keuangan yang umumnya adalah "jangka panjang" bagi negara berkembang antara lain: a) adanya tambahan dana segar baru, b) perbaikan dalam infrastruktur pasar keuangan, dan c) pembangunan dalam sektor keuangan. Dalam konteks ini globalisasi keuangan dianggap dapat memecahkan permasalahan informasi yang asimetris (asymmetric information) dengan pembangunan infrastruktur yang lebih baik, karena globalisasi keuangan mendorong terjadinya transparansi dan akuntabilitas yang lebih tinggi di sektor keuangan. Selain itu, dengan pembangunan di sektor keuangan menciptakan peluang diversifikasi aset bagi masyarakat sehingga diharapkan dapat memecahkan masalah pembagian resiko atau risk sharing. Terakhir, disiplin pasar akan semakin meningkat dengan adanya globalisasi keuangan.

Namun dalam Schumekler $^{19}$ dijelaskan juga bagaimana globalisasi keuangan telah menciptakan resiko krisis keuangan dan biaya ekonomi yang sangat tinggi. Setidaknya ada empat (4) alasan mengapa hal ini bisa terjadi. Pertama, dengan meliberalisasi pasar keuangan, maka negara tersebut akan menjadi subyek disiplin pasar yang akan dilakukkan oleh investor domestik maupun luar negeri. Kedua, globalisasi keuangan akan menyebabkan krisis keuangan jika terjadi ketidaksempurnaan dalam pasar keuangan global. Hal inilah yang pada akhirnya akan mendorong terjadinya bubles economy, herding behaviour, dan perilaku yang

19 Schmukler, S. L., "Financial Globalization: Gain and Pain for Developing Countries," Federal Reserve Bank of Atlanta E c o n o m i c R e vi e w Second Quarter, 2004. 
irasional serta serangan spekulasi. Ketiga, krisis keuangan akibat globalisasi keuangan akan menyebabkan suatu negara tergantung pada faktor eksternal. Sebagai contoh, jika Indonesia tergantung pada modal luar negeri "jangka pendek" maka keluarnya modal luar negeri tersebut secara tiba-tiba akan menyebabkan krisis bagi Indonesia. Terakhir, krisis keuangan akibat globalisasi keuangan akan terjadi karena kemungkinan penularan krisis (contagion) karena semakin terintegrasinya keuangan antar negara.

Tingginya ancaman resiko keuangan dan perbankan akibat mismanagement dalam liberalisasi keuangan juga diperkuat oleh pandangan Mishkin $^{20}$ yang berpandangan bahwa liberalisasi keuangan telah mendorong aktivitas perbankan yang cenderung mengambil posisi resiko yang lebih tinggi. Bahkan pertumbuhan kredit mampu mencapai tingkat $15-30 \%$ pertahun, atau meningkat dua kali lipat dari pertumbuhan yang normal. Keadaan ini diperparah dengan kurangnya keahlian manajemen bank di negara berkembang dalam mengelola resiko, sehingga menyebabkan keterbukaan resiko yang semakin tinggi di negara-negara berkembang.

Pandangan ini sejalan dengan hasil empiris Mc Kinnon and Pill ${ }^{21}$ yang secara umum menjelaskan kondisi overborrowing atau pinjaman luar negeri yang berlebihan, yang menyebabkan mereka terperangkap dalam dua resiko sekaligus (resiko nilai tukar dan resiko kredit).

20 Mishkin, F. S., "Is Financial Globalization Beneficial?," Journal of Money, Credit and Banking, Vol. 39, No. 2-3 (March-April 2007).

21 McKinnon, R. I., and Pill, H., "Credible Economic Development and over-Borrowing," American Economic Review, 87 (2) 189-193.
Permasalahan globalisasi keuangan yang menciptakan efek yang negatif bagi pengembangan sektor keuangan pada dasarnya disebabkan oleh kurangnya regulasi dan supervisi di sector keuangan. Hal ini secara umum telah menyebabkan pelaku perbankan untuk tidak membatasi resikonya dan terekspos dalam keterbukaan resiko yang tinggi. Sehingga pada akhirnya, resiko yang dialami oleh beberapa bank menyebabkan efek domino dan krisis yang berkepanjangan bagi pengembangan sektor perbankan itu sendiri, dan sektor-sektor lainnya.

Selanjutnya, permasalahan globalisasi keuangan, dengan hadirnya bank-bank asing di negara-negara berkembang, juga masih menimbulkan pro kontra yang belum menemui titik konsensus. Pandangan yang "pro" terhadap masuknya bank asing di pasar domestik memiliki ide dasar bahwa masuknya bank asing akan memberikkan warna kompetisi yang sehat sehingga dapat menurunkan biaya dana dan menciptakan efisiensi pada pasar keuangan domestik. Secara umum Levine $^{22}$ menjelaskan keuntungan masuknya bank asing, antara lain:

a. Meningkatkan kualitas dan ketersediaan jasa keuangan dalam pasar domestik.

b. Menstimulasi pengembangan dalam supervisi dan regulasi bank.

c. Meningkatkan aksesibilitas pada pasar keuangan internasional.

d. Memberikan kontribusi pada stabilitas keuangan.

22 Levine, R., "Financial Development and Economic Growth," Policy Research Working hlm. 1678 . 
Hal ini diperkuat oleh pandangan Mishkin $^{23}$ yang menjelaskan keuntungan masuknya bank asing, antara lain:

a. Bank asing cenderung less risk karena kemampuannya dalam manajemen resiko, sehingga mendorong terjadinya stabilitas keuangan dalam pasar domestik.

b. Bank asing akan meningkatkan implementasi best practices dalam perbankan domestik.

c. Dengan banyaknya bank asing, maka pemerintah akan mengurangi fungsinya dalam mem-bail out. Hal ini tentu akan menyehatkan sistem perbankan domestik.

Namun, pandangan yang kontra terhadap benefit masuknya bank asing ke pasar domestik diungkapkan oleh Agenor $^{24}$, bahwa secara empiris masuknya bank asing kurang memberikan akses terhadap kredit mikro dan menengah. Kedua, masuknya bank asing yang cenderung memiliki biaya operasional yang rendah mendesak perbankan tanah air untuk melakukan merger agar bisa lebih kompetitif. Proses perubahan struktur inilah yang akan menyebabkan permasalahan baru berkaitan dengan "too big too fail" atau "too political too fail", yang mana stabilitas keuangan akan semakin terancam dengan bangkrutnya bank besar di tanah air. Terakhir, bank asing cenderung berperilaku "cut and run" jika terjadi krisis

23 Dalam Schmukler, S. L., "Financial Globalization: Gain and Pain for Developing Countries, "Federal Reserve Bank of Atlanta E c o n o m i c R e vi e w Second Quarter, 2004.

24 Agénor, P.-R., "Benefits and Costs of International Financial Integration: Theory and Facts," This paper was prepared for the conference on Financial Globalization: Issues and Challenges for Small States (Saint Kitts, 2728 March, 2001). atau permasalahan dalam pasar domestik, sehingga menyebabkan instabilitas bagi sistem keuangan domestik.

\section{Kebijakan Dasar Foreign Portofolio Investment}

Pada umumnya, foreign portofolio investment termasuk dalam jenis investasi asing, yang keberadaannya sama pentingnya dengan investasi langsung (foreign direct investment). Namun demikian, dalam Undang-Undang Nomor 25 Tahun 2007 tentang Penanaman Modal, tidak disebutkan perihal kebijakan foreign portofolio investment melainkan hanya foreign direct investment saja. Hal ini dapat dilihat pada bagian umum dan pasal 2 (dua) sebagai berikut: "Undang-undang ini mencakupi semua kegiatan penanaman modal langsung di semua sektor".

Selanjutnya, penjelasan Pasal 2 UU No. 25 tahun 2007 tentang Penanaman Modal menyebutkan: "Yang dimaksud dengan penanaman modal di semua sektor di wilayah Negara Republik Indonesia" adalah penanaman modal langsung dan tidak termasuk penanaman modal tidak langsung atau portofolio". Oleh karena itu, penanaman modal tidak langsung (foreign portofolio investment) tidak termasuk dalam ruang lingkup UU No. 25 Tahun 2007 tentang Penanaman Modal.

Sebagaimana telah dijelaskan pada bab sebelumnya foreign portofolio investment berdasarkan mekanisme operasionalnya dilakukan melalui pasar modal baik di pasar perdana maupun pasar sekunder, sehingga hal ihwal foreign portofolio investment diatur dalam Undang-Undang Pasar Modal, yakni Undang-Undang Nomor 8 Tahun 1995 sebagaimana disebutkan pada pasal 1 (satu) undang-undang ini. 
Pasar modal dibentuk berdasarkan kebutuhan perkembangan ekonomi nasional suatu negara. Dalam pembangunan ekonomi tersebut dibutuhkan mobilisasi dana dari masyarakat untuk pembiayaan pembangunan. Memperhatikan perkembangan sejarah pasar modal, perkembangan secara evolutif (bottom up process) banyak ditemukan di negeranegara kapitalis-liberal, sedangkan di Indonesia pendekatannya lebih diarahkan kepada kebijaksanaan pembangunan nasional (top bottom process). ${ }^{25}$ Pengembangan pasar modal di Indonesia sebagaimana digariskan Garis-garis Besar Haluan Negara (GBHN) adalah menuju pemerataan pendapatan (yang merupakan program pemerintah) dan mobilisasi dana dalam negeri untuk pembangunan, ${ }^{26}$ sehingga foreign portofolio investment memainkan peranan yang penting dalam sistem ekonomi dan pemerintah di berbagai penjuru dunia. Dalam kapasitasnya selaku regulator, pemerintah mempengaruhi evolusi dan perkembangan dari pasar keuangan dimaksud dan kelembagaan lain. $^{27}$

Pada tanggal 7 Januari 1980, Presiden RI telah pula mengeluarkan ajakan sebagai berikut: "Kepada mereka yang memiliki uang yang tidak dapat atau tidak mau menanamkan uangnya dalam investasi proyek, akan terus dirangsang agar menyimpan uangnya pada deposito berjangka, Tabanas, dan Taska atau

25 Umaran Mansyur, Teknik Perdagangan Efek di Bursa Efek Indonesia, Aksara Kencana, Jakarta, 1986, hlm. 7.

26 Ibid.

27 Frank Fabozzi dan Franco Modigliani, Capital Market, Institution, and Instrumen, Prentice Hall, New Jersey, 1996, hlm. 28. menggunakan kesempatan yang menarik untuk memasuki Pasar Modal". ${ }^{28}$

Foreign portofolio investment dilakukan negara karena dana yang dimiliki pemerintah (domestik) tidak cukup untuk membiayai pembangunan dalam skala besar, sehingga pemerintah menerapkan kebijakan foreign portofolio investment dengan menerbitkan instrumen-instrumen obligasi baik korporasi maupun negara melalui pasar perdana (pemerintah) maupun pasar sekunder (pasar modal), sehingga terjadi keseimbangan antara investasi langsung (foreign direct investment) dengan tidak langsung (foreign portofolio investment). Keseimbangan itu diperlukan agar apabila pada suatu saat investasi langsung tidak menunjukkan perkembangan yang berarti peranannya, maka dapat digantikan oleh investasi tidak langsung (foreign portofolio investment).

\section{Kebijakan Liberalisasi Foreign Portofolio Investment di Indonesia}

Kebijakan liberalisasi keuangan (foreign portofolio investment), industri, dan perdagangan juga telah dilakukan jauh sebelum krisis tahun 1997. Bahkan, berbeda dengan negara-negara Asia lain, seperti China, Jepang, dan Korea, yang menempatkan liberalisasi keuangan pada urutan paling akhir, Indonesia justru memprioritaskan liberalisasi keuangan sebelum membangun industri domestik yang tangguh. ${ }^{29}$

Dengan Pakto 88 (Paket Kebijakan tahun 1988), berbagai liberalisasi dimulai, seperti diperbolehkannya untuk membuka

28 Disampaikan dalam keterangan Pemerintah tentang RAPBN 1980/1981.

29 Hendri P., 'Pembangunan tanpa roh', Kompas, 7 Juli 2010 (online), <http://koran.kompas.com/read/xml/2010/07/07/04465448/.html > diakses pada tanggal 2 Januari 2010, Pukul 20.00 WIB 
bank baru hanya dengan modal $\mathrm{Rp} 10$ miliar, bank-bank asing lama ataupun baru diberi kemudahan membuka cabang, bentuk patungan antarbank asing dengan bank swasta nasional diizinkan, rasio kecukupan modal bank lokal diturunkan dari $15 \%$ menjadi $2 \%$, dan sebagainya.

Apabila saat ini sektor keuangan Indonesia menjadi sangat liberal, maka sangat wajar. Tidak adanya kontrol terhadap modal jangka pendek, misalnya, telah mengakibatkan sektor keuangan rapuh karena tingginya kepemilikan asing pada Surat Utang Negara (SUN) ataupun Sertifikat Bank Indonesia (SBI). Percepatan liberalisasi di sektor perbankan juga terus dilakukan, misalnya melalui Peraturan Presiden (Perpres) Nomor 111 Tahun 2007 yang memberikan peluang bagi asing untuk menguasai hingga 99 persen saham perbankan nasional.

Apabila dikaji lebih jauh masih banyak kebijakan ekonomi yang mengakibatkan keterpurukan ekonomi saat ini, yang sebenarnya telah diawali pada masa Orde Baru (Orba) karena sejatinya kebijakan ekonomi era Reformasi hingga era saat ini masih merupakan lanjutan dari arah kebijakan ekonomi Orba. Mungkin peribahasa "bagaimana biduk, bagaimana pengayuh" tepat untuk menggambarkannya, yang berarti bagaimana pilihan kebijakan orang tua, begitulah pilihan anaknya.

Hanya memang harus diakui juga bahwa ada faktor lain yang mengakibatkan kondisi ekonomi saat ini lebih buruk dibanding era Orde Baru (Orba), terutama akibat peran negara yang semakin dibatasi dan liberalisasi yang semakin cepat dan tanpa arah. Sebagai contoh, program kredit Bimas dan Inmas atau kewajiban alokasi kredit kepada UKM lewat Kredit Usaha Kecil (KUK) pada masa Orba, saat ini tidak mungkin dilakukan karena tangan pemerintah telah dipatahkan satu per satu lewat liberalisasi. Kredit Usaha Rakyat (KUR) ala kabinet Susilo Bambang Yudhoyono (SBY) sangat berbeda karena tidak dilakukan dengan menggunakan dana pemerintah, tetapi dana komersial bank yang ikut dalam program sehingga wajar bila realisasinya rendah.

Pada kurun waktu antara periode 1980-2001, liberalisasi foreign portofolio investment masih dalam bentuk liberalisasi pada korporasi (perusahaan) yang melakukan go public ke pasar modal. Namun, dalam bentuk foreign portofolio investment pemerintah (obligasi negara) masih sangat minim, yaitu dalam Sertifikat Bank Indonesia (SBI) saja. Akan tetapi, dalam kurun waktu 2002-2008 pemerintah telah melakukan penerbitan UndangUndang Nomor 24 tahun 2002 (masa pemerintahan Megawati Soekarno Putri) hingga pada masa pemerintahan Susilo Bambang Yudhoyono, yakni UndangUndang Nomor 19 Tahun 2008 tentang Surat Berharga Syari'ah Negara (SBSN) dan Obligasi Ritel Negara tahun 2006. Penerbitan Undang-Undang ini merupakan manifestasi awal diberlakukannya kebijakan liberalisasi foreign portofolio investment. Beberapa foreign portofolio investment selain obligasi korporasi adalah obligasi negara sebagai salah satu jenis foreign portofolio investment yang sangat berhubungan dengan bisnis perbankan adalah sebagai berikut:

\section{a. Undang-Undang Nomor 24 Tahun 2002 tentang Surat Utang Negara (SUN)}

Untuk menjamin keberadaan obligasi yang diterbitkan oleh pemerintah Republik Indonesia atau yang lebih dikenal dengan Surat Utang Negara (SUN), maka sejak 
tanggal 22 Oktober 2002 pemerintah telah mengesahkan Undang-Undang Nomor 24 Tahun 2002 tentang Surat Utang Negara (SUN). Pengesahan Undang-Undang tersebut menjadi hal yang sangat penting dan paling diminati oleh para investor, baik oleh investor asing maupun domestik. Dasar pertimbangan pemerintah pada saat menyusun dan mengesahkan undangundang tersebut adalah dalam rangka mendukung keberhasilan pembangunan nasional guna mewujudkan masyarakat yang adil, makmur, dan sejahtera berdasarkan Pancasila dan Undang-Undang Dasar 1945.

Dalam konteks kemandirian bangsa, potensi yang tersedia di dalam negeri harus dioptimalkan untuk melaksanakan kegiatan ekonomi dan membiayai kegiatan pembangunan. Sehubungan dengan hal tersebut, pemerintah perlu diberikan peluang untuk meningkatkan akses yang dapat menggali potensi sumber pembiayaan pembangunan dan memperkuat basis pemodal domestik. Pembiayaan tersebut akan terjamin keamanannya apabila mobilisasi dana masyarakat disertai dengan bekerjanya sistem keuangan, meliputi sistem perbankan, pasar uang, dan pasar modal yang efisien. Terciptanya keragaman dalam mobilisasi dana dapat menghasilkan sistem keuangan yang kuat dan memberikan alternatif bagi para pemodal (investor).

Dalam kegiatan di pasar keuangan, peranan pasar Surat Utang Negara (SUN) sangat strategis. Artinya, tingkat imbal

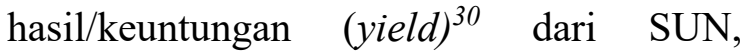

30 Imbal hasil (yield) dari foreign portofolio investment terdiri dari 2 (dua) komponen yakni capital gain yang berupa kenaikan dari nilai akhir investasi dibandingkan dengan nilai awalnya, serta pendapatan secara berkala dalam bentuk dividend atau coupon/interet. sebagai instrumen keuangan yang bebas resiko, dipergunakan oleh para pelaku pasar sebagai acuan atau referensi dalam menentukan tingkat keuntungan suatu investasi atau aset keuangan lain. Dengan demikian, penerbitan SUN secara teratur dan terencana diperlukan untuk membentuk suatu tolak ukur yang dapat dipergunakan dalam menilai kewajiban suatu harga aset keuangan atau surat berharga.

Adanya pasar keuangan yang efisien akan memberikan beberapa manfaat, antara lain: ${ }^{31}$

1) Memberikan peluang dan partisipasi yang lebih besar kepada pemodal untuk melakukan diversifikasi portofolio investasinya.

2) Membantu terciptanya suatu tata kelola yang baik (governance) dikarenakan adanya tingkat transparansi informasi keuangan yang tinggi dalam pasar modal.

3) Membantu terwujudnya suatu sistem keuangan yang stabil karena berkurangnya resiko sistemik (systemic risk) akibat menurunnya ketergantungan pada modal yang berasal dari sistem perbankan.

Dari sisi mobilisasi dana masyarakat melalui mekanisme APBN, penggunaan SUN secara potensial dapat mengurangi ketergantungan pada pembiayaan luar negeri yang sangat rentan terhadap fluktuasi nilai tukar. Di samping itu, pengelolaan SUN secara baik dan benar dapat mengurangi kerugian negara yang ditimbulkan oleh berbagai resiko keuangan dalam portofolio utang negara melalui mekanisme APBN, maka dengan sendirinya akan terselenggara sistem

31 Penjelasan atas Undang-Undang Republik Indonesia Nomor 24 Tahun 2002 tentang Surat Utang Negara, Bagian Umum. 
pengawasan langsung oleh publik. ${ }^{32}$ Oleh karena itu, melalui Undang-Undang Republik Indonesia Nomor 24 Tahun 2002 tentang Surat Utang Negara (SUN), pemerintah mengatur hal-hal sebagai berikut: ${ }^{33}$

1) Transparansi pengelolaan SUN dalam kerangka kebijakan fiskal dan kebijakan pengembangan pasar SUN dengan mengatur lebih lanjut tentang tujuan penerbitan SUN.

2) Kewenangan pemerintah untuk menerbitkan SUN yang didelegasikan kepada Menteri Keuangan, misalnya dalam menentukan persyaratan dan ketentuan (term and condition) SUN.

3) Kewenangan pemerintah untuk membayar semua kewajiban yang timbul dari penerbitan SUN tersebut secara penuh dan tepat waktu sampai berakhirnya kewajiban tersebut.

4) Landasan hukum bagi pengaturan lebih lanjut atas tata cara penerbitan SUN di pasar perdana maupun di pasar sekunder agar pemodal memperoleh kepastian untuk memiliki dan memperdagangkan SUN secara mudah dan aman.

Beberapa poin yang penting mengenai SUN adalah (1) Tema pokok UU SUN adalah memberikan "standing appropriation", yaitu jaminan pemerintah kepada pasar untuk membayar semua kewajiban pokok dan bunga utang yang timbul akibat penerbitan SUN, (2) Surat Utang Negara terdiri dari Surat Perbendaharaan Negara (SPN) semacam $T$ Bills di AS dan Obligasi Negara (ON).

Surat Perbendaharaan Negara (SPN) merupakan Surat Utang Negara (SUN) berjangka waktu sampai dengan 12 bulan

32 Ibid.
33 Ibid. dengan pembayaran bunga secara diskonto (mirip Sertifikat Bank Indonesia), sedangkan Obligasi Negara (ON) merupakan SUN berjangka waktu lebih dari 12 bulan dengan kupon dan atau pembayaran bunga secara diskonto. Tujuan penerbitan Surat Utang Negara (SUN) adalah (1) Membiayai defisit APBN, yaitu menutup kekurangan kas jangka pendek akibat ketidaksesuaian antara arus kas penerimaan dan pengeluaran pada rekening kas negara dalam satu tahun anggaran, (2) mengelola portofolio utang negara.

\section{b. Obligasi Ritel Negara (ORI) tahun 2006}

Pada tanggal 9 Agustus 2006, untuk pertama kalinya Pemerintah menerbitkan obligasi negara berbasis Ritel, atau disebut Obligasi Negara Ritel (ORI) dengan seri ORI-001. Obligasi Negara Ritel (ORI) adalah obligasi negara yang dijual kepada individu atau perseorangan Warga Negara Indonesia melalui agen penjual di pasar perdana. Penerbitan ORI-001 merupakan salah satu upaya untuk melakukan strategi pengelolaan utang negara tahun 2005-2009 yang telah ditetapkan oleh Menteri Keuangan Nomor 447/KMK 06/2005 tentang Strategi Pengelolaan Utang Negara tahun 2005-2009. Di dalam dokumen strategi dimaksud ditetapkan bahwa pengembangan pasar sekunder Surat Utang Negara (SUN) dilakukan antara lain dengan melakukan diversifikasi instrumen Surat Utang Negara (SUN) melalui SUN ritel yang mana hal ini sejalan pula dengan upaya memperluas basis investor.

Penerbitan ORI merupakan langkah nyata pemerintah dalam melakukan strategi dimaksud. Selain itu, ORI diterbitkan juga dalam rangka memberikan alternatif investasi yang cukup menguntungkan dan aman bagi investor individu, serta 
memberikan unsur pendidikan bagi investor individu untuk berinvestasi pada instrumen pasar modal seperti ORI. ORI-001 jatuh tempo pada tanggal 9 Agustus 2009 atau memiliki umur 3 tahun, tingkat kuponnya $12,05 \%$ yang dibayar bulanan, dan dapat diperjualbelikan. ${ }^{34}$

\section{c. Undang-Undang Nomor 19 Tahun 2008 Tentang Surat Berharga Syari'ah Negara (SBSN) \\ Rancangan Undang-undang (RUU)} Surat Berharga Syariah Negara (SBSN) disahkan menjadi Undang-Undang pada rapat paripurna Dewan Perwakilan Rakyat Republik Indonesia (DPR RI) di Gedung DPR Jakarta pada tanggal 9 April 2008. Pembahasan RUU SBSN ini telah berlangsung sejak tahun 2005.

Surat Berharga Syariah Negara (SBSN) atau dapat juga disebut Sukuk Negara adalah merupakan surat berharga yang diterbitkan oleh pemerintah_Republik Indonesia berdasarkan prinsip syariah. Perusahaan yang akan menerbitkan SBSN ini adalah merupakan perusahaan yang secara khusus dibentuk guna kepentingan penerbitan SBSN ini (special purpose vehicle-SPV).

SBSN atau sukuk negara ini adalah merupakan suatu instrumen utang piutang tanpa riba sebagaimana dalam obligasi, di mana sukuk ini diterbitkan berdasarkan suatu aset acuan yang sesuai dengan prinsip syariah.

Surat Berharga Syariah Negara (SBSN) dapat berupa (1) Surat Berharga Syariah Negara (SBSN) ijarah, yaitu SBSN yang diterbitkan berdasarkan akad ijarah akad sewa menyewa atas suatu aset, (2)

34 Laporan Pertanggungjawaban Pengelolaan Surat Utang Negara 2006, Disampaikan sebagai bagian pertanggungjawaban pelaksanaan APBN 2006, hlm. 13-14.
SBSN mudharabah, yaitu SBSN yang diterbitkan berdasarkan akad mudharabah (akad kerjasama dimana salah satu pihak menyediakan modal ( $r a b$ al-maal) dan pihak lainnya menyediakan tenaga dan keahlian (mudharib) dimana kelak keuntungannya akan dibagi berdasarkan persentase yang disepakati sebelumnya, apabila terjadi kerugian maka kerugian tersebut adalah menjadi beban dan tanggung jawab pemilik modal, (3) SBSN musyarakah, yaitu SBSN yang diterbitkan berdasarkan akad musyarakah (akad kerjasama dalam bentuk penggabungan modal), (4) SBSN istisna', yaitu SBSN yang diterbitkan berdasarkan akad istisna, (akad jual beli untuk pembiayaan suatu proyek dimana cara ,jangka waktu penyerahan barang dan harga barang ditentukan berdasarkan kesepakatan para pihak. Surat Berharga Syariah Negara (SBSN) berdasarkan akad lainnya sepanjang tidak bertentangan dengan prinsip syariah, SBSN yang diterbitkan berdasarkan kombinasi dari dua atau lebih jenis akad.

Instrumen-instrumen ini telah menghantarkan Indonesia sebagai negara Emerging Market di dunia pasca krisis keuangan yang melanda Amerika Serikat dan Eropa tahun 2008. Bahkan, Indonesia juga telah tergolong sebagai negara yang layak menerima predikat "Investment Grade" karena pencapaian masuknya dana asing yang sangat besar di samping negaranegara lainnya. Hal ini disebabkan karena Indonesia belum memiliki instrumen kebijakan yang berisi ketentuan-ketentuan pembatasan dana asing sebagaimana negara-negara lain di dunia, khususnya di kawasan Asia.

\section{Kedudukan dan Kewenangan} Pemerintah dalam Penerbitan dan 
Perdagangan Foreign Portofolio

Investment dikaitkan

dengan

\section{Kepentingan Asing}

Pada setiap penerbitan foreign portofolio investment, baik Obligasi Negara maupun Korporasi Pemerintah melakukan perbuatan hukum yang memiliki sifat keperdataan. Pemerintah dianggap melakukan kegiatan komersial yang harus dibedakan dari kegiatan menjalankan pemerintahan. Kedudukan hukum pemerintah pemerintah dalam hal ini adalah sebagai penerbit (issuer) dari Obligasi Negara maupun Obligasi Korporasi. Dengan melakukan penerbitan Obligasi Negara maupun Korporasi, pemerintah menundukkan diri kepada aturan-aturan dalam hukum perdata yang berkaitan dengan penerbitan Obligasi Negara maupun Korporasi. ${ }^{35}$

Setelah Obligasi Negara maupun Korporasi diterbitkan, kegiatan pemerintah yang berkaitan dengan aktivitas komersial sementara berhenti, yang kemudian muncul kembali di kemudian hari berkaitan dengan kewajiban pemerintah untuk membayar bunga dan pokok Obligasi Negara pada saat jatuh tempo. Tindakan hukum pemerintah di kedua momentum tersebut seperti mempergunakan hasil penjualan Obligasi Negara sesuai dengan tujuan penerbitannya tidak termasuk kedalam kegiatan komersial, tetapi termasuk ke dalam kegiatan menjalankan pemerintahan. Dari uraian di atas, dapat dilihat dengan jelas bahwa pemerintah mempunyai dual personality dalam penerbitan dan pemanfaatan Obligasi Negara, yang melakukan kegiatan yang berkaitan dengan

35 Jonker Sihombing, Investasi Asing melalui Surat Utang Negara di Pasar Modal, Bandung, PT Alumni, 2008, hlm. 202 aktivitas komersial dan aktivitas pemerintahan secara bersamaan.

Dalam kaitannya dengan Obligasi Negara yang diterbitkan pemerintah, investor asing pada dasarnya berkeinginan untuk mengetahui apabila pemerintah Indonesia tidak bisa menunaikan kewajibannya pada waktunya, baik berupa pembayaran bunga maupun utang pokok, apakah perbuatan hukum tersebut dapat dikatakan perbuatan melawan hukum atau hanya sebagai perbuatan wan prestasi?

Apabila dilihat secara sepintas, akan kelihatan bahwa setiap perbuatan hukum yang dilakukan pemerintah dalam penerbitan Obligasi Negara yang tidak sesuai dengan maksud dan tujuan semula seakan-akan dapat digolongkan sebagai perbuatan yang bertentangan dengan undang-undang, yaitu Undang-Undang Nomor 24 Tahun 2002 Tentang Surat Utang Negara (SUN). Namun, apabila diteliti lebih jauh pada dasarnya UU No. 24 tahun 2002 hanya memuat tentang pengaturan tentang kewenangan penerbitan, tujuan penerbitan, penatausahaan, kegiatan lelang, serta pengelolaan surat utang negara. Memang, UU tersebut mengatur juga kedudukan pemerintah baik yang menyangkut perbuatan komersial maupun perbuatan menjalankan pemerintahan, tetapi tidak menyinggung adanya hubungan hukum antara pemerintah sebagai penerbit surat utang negara di satu sisi dengan investor asing sebagai pembeli dan pemegang surat utang negara disisi lainnya. Dalam kehidupan sehari-hari adanya kedudukan ini menunjukkan tidak adanya ikatan yang kuat antara pemerintah dan investor atas hukum, sehingga mengakibatkan legalitas atas kebebasan asing dalam berinvestasi maupun berdivestasi. Dengan kata lain investor dan pemerintah memiliki kedudukan yang 
sama, bahkan cenderung akan berimplikasi atas kecenderungan kedudukan yang lebih tinggi oleh investor (asing maupun domestik).

\section{Kebijakan Liberalisasi Foreign Portofolio Investment di beberapa Negara di Kawasan Asia.}

Berbeda dengan kebijakan foreign portofolio investment di Indonesia, sebagaimana diketahui bahwa baru-baru ini, negara-negara emerging market yang menjadi sasaran capital inflow mulai menaikkan pajak atas dana asing. Misalnya, Brasil yang menaikkan pajak hingga dua kali lipat terhadap dana asing yang masuk ke surat utang (domestik debt), demikian pula Thailand yang menambahkan pajak baru senilai $15 \%$ terhadap dana asing yang masuk ke surat utang.

Kebijakan tersebut dilakukan untuk memperketat masuknya dana asing yang bersifat jangka pendek atau hot money agar tidak membanjiri pasar keuangan. Hot money memang bisa menjadi pemicu bubble atau gelembung ekonomi. Itu jika terjadi arus pembalikan modal secara tibatiba (sudden reversal) bisa membuat perekonomian sebuah negara kolaps, sebagaimana telah terjadi pada negaranegara di Asia seperti Malaysia, Thailand, Korea Selatan, China, Jepang, India, dan Pilipina dan termasuk indonesia pada sekitar tahun 1990-an. ${ }^{36}$

Sebagian besar negara-negara tersebut (Asia/negara-negara berkembang) telah segera berbenah dengan kebijakan pembatasan arus sirkulasi dana asing (capital inflow) melalui pajak, terkecuali

36 Chung H. Lee, 'Financial Liberalization and the Economic Crisis in Asia', University of Hawaii at Manoa, East-West Center, and European Institute of Japanese Studies Stockholm School of Economics, p.7
Indonesia. Saat ini, tak diragukan lagi, Indonesia menjadi salah satu negara yang memiliki magnet kuat di mata investor. Data Bank Indonesia (BI) menunjukkan, sepanjang Januari-September 2010 saja, Rp. 115 triliun dana asing sudah membanjiri pasar finansial di Indonesia. Dari jumlah tersebut, Rp. 74 triliun masuk ke instrumen Surat Utang Negara (SUN), sisanya melalui pasar saham dan Sertifikat Bank Indonesia (SBI). ${ }^{37}$

Di samping itu, sebagian besar negara-negara di kawasan Asia maupun Amerika Latin telah mempunyai kebijakan (regulasi) khusus yang mengatur masalah pembatasan dana terhadap foreign portofolio Investment. Misalnaya, pada pemerintah China menerapkan kebijakan memperkuat liberalisasi keuangan (foreign portofolio Investment) domestik dengan berbagai pembatasan dan analisis manajemen resiko yang ketat (jeli) dan sebagainya. ${ }^{38}$ Hal ini juga mengakibatkan timbulnya efek hukum yang berarti bahwa negar-negara tersebut menjadi lebih tinggi kedudukannya daripada negara-negara investor, sehingga dapat menjadi instrumen ikatan hukum kedua negara dalan menjalin investasi internasional. Fenomena ini bertolak belakang atas Indonesia yang secara eksplisit bermakna menimbulkan efek hukum yang sama anatar host contry dengan investor asing. Sehingga, investor dapat dengan leluasa melakukan investasi dan divestasi kapanpun berkehendak. Dengan demikian, Indonesia tergolong negara yang sangat liberal dibanding dengan negara-negara berkembang lainnya,

37 Bisnis Indonesia (online), <http://www.kendarinews.com/berita.html $>$, diakses pada tanggal 8 Desember 2010.

38 European Socio-economic research (online), $<$ http://ec.europa.eu/economy finance/publications.html $>$ diakses pada tanggal 1 Desember 2010 . 
bahkan dengan negara-negara maju seperti Jepang dan China.

\section{Faktor-faktor yang Mendorong Liberalisasi Foreign Portofolio Investment}

Motivasi investasi asing di pasar modal adalah untuk mendapatkan keuntungan dengan tetap mempertimbangkan resiko yang melekat pada instrumen investasi asing tersebut. Investasi di pasar modal sifatnya lebih cair dibandingkan dengan investasi langsung dalam bentuk kepemilikan proyek, dan investasi di pasar modal dapat berpindah tempat dalam waktu yang relatif singkat. Secara umum, investasi asing menginginkan agar investasinya dipasar modal mempunyai: ${ }^{39}$

a. Kebebasan dalam kepemilikan instrumen pasar modal

b. Kebebasan menetapkan sendiri nilai investasinya,

c. Perlakuan yang sama dalam hukum dan kedudukan,

d. Konsistensi dalam pelaksanaan peraturan-peraturan,

e. Ada jaminan berinvestasi dan berusaha,

f. Diterima keberadaannya sebagai mitra pembangunan,

g. Birokrasi yang transparan dan lancar,

h. Kepastian hukum dan penegakan hukum.

Motif dari investasi asing pada obligasi pemerintah/obligasi negara sama dengan motif investasi asing pada pasar modal pada umumnya sebagaimana yang telah disebutkan di atas. Pada dasarnya,

39 Nindyo Pramono, Sertifikasi Saham PT Go Public dan Hukum Pasar Modal di Indonesia, edisi kedua, Penerbit PT Aditya Bakti, Bandung 2001, hlm.183 investasi asing mempunyai akses untuk mendapatkan data-data dan informasi yang berkenaan dengan obligasi pemerintah/negara, dan mereka dapat membeli obligasi negara sebesar yang diinginkan karena tidak adanya pembatasan kepemilikan bagi investor asing. Ketentuan perundang-undangan yang berkenaan dengan obligasi negara tidak memberikan perbedaan antara investor asing dengan investor dalam negeri. Investor asing dapat melakukan investasi dan divestasi kapan dikehendaki, dan hal itu menjadi motivasi tambahan bagi pihak asing untuk berinvestasi pada obligasi negara. Investor asing akan merasa aman untuk berinvestasi karena dapat menjual Obligasi Negara kapanpun dibutuhkan. Jumlah invesati pada Obligasi Negara relatif lebih besar daripada Obligasi Korporasi, oleh karena itu Obligasi Negara tergolong sangat likuid.

Pada umumnya, surat berharga yang diterbitkan pemerintah digolangkan kedalam investasi bebas resiko (risk free investment). Hal yang sama dianut di Amerika Serikat, surat utang yang diterbitkan pemerintah (treasury notes dan treasury bonds) digolongkan sebagai investasi yang tinggi kualitasnya. Faktor risk free investment tersebut turut menjadi pertimbangan bagi investor asing untuk berinvestasi pada Obligasi Negara.

Dari motivasi investasi asing yang pada dasarnya dimaksudkan untuk mendapatkan keuntungan sebagaimana yang telah disebutkan di atas, pemerintah perlu menaruh perhatian atas peningkatan kepemilikan pihak asing atas Obligasi Negara. Apabila sebagian besar Obligasi Negara dikuasai oleh pihak asing, hal tersebut akan mempunyai akibat hukum yang mempengaruhi alokasi keuangan negara, karena pembayaran bunga yang menjadi beban APBN akan jatuh ke tangan 
pihak asing. Selanjutnya, melalui kepemilikan sebagian besar Obligasi Negara, pihak asing secara tidak langsung menjadi ikut mempengaruhi proses pembangunan nasional, karena setiap langkah yang akan ditempuh oleh pemerintah untuk menyukseskan pembangunan akan diketahui dan sedikit banyak akan turut dipengaruhi oleh pihak asing. Kepemilikan asing atas Obligasi Negara yang terlalu besar tersebut tidak sejalan dengan prinsip kebersamaan dan kemandirian dalam pembangunan ekonomi nasional.

Sunaryati Hartono, menyebutkan bahwa dominasi dari investasi asing di Indonesia dapat dilihat sebagai bentuk lain dari kolonialisme baru (postkolonialisme ${ }^{40}$ ). Apabila dominasi dari pihak asing pada investasi langsung (foreign direct investment) dapat dicegah dengan cara pemerintah lebih selektif dalam menerbitkan ijin-ijin investasi, untuk investasi Obligasi Negara seperti ini tidak dapat dilaksanakan karena investor asing dapat membeli instrumen tersebut dipasar modal sebesar yang mereka inginkan. Campur tangan pihak asing dalam menentukan arah pembangunan ekonomi dapat dilihat dati peran International Monetary Fund (IMF) pada krisis moneter 1998, dan rekomendasinya mutlak harus dituruti pemerintah. Dengan campur tangan IMF tersebut, pemerintah menjadi tidak

40 Sunaryati Hartono, Beberapa masalah Transnasional dalam Penanaman Modal Asing di Indonesia, Penerbit Bina Cipta, Bandung, 1972, hlm. $336 . \quad$ Sunaryati Hartono menyebutkan bahwa untuk mencegah investasi asing menjadi bentuk kolonialisme baru dapat ditempuh dengan cara mengikutsertakan sebanyak mungkin Negara peserta di dalam tiaptiap bidang usaha (spreading of participants), sehingga tidak ada suatu perusahaan atau negarapun yang mempunyai kedudukan monopoli. bebas untuk menentukan resep pemulihan ekonomi sesuai dengan keyakinannya sendiri. Berikut akan dijelaskan lebih rinci faktor-faktor lain di samping motivasi keuntungan sebagaimana telah disebutkan pada penjelasan di atas. Beberapa hal yang mendorong liberalisasi foreign portofolio investment tersebut adalah sebagai berikut.

\section{Pengaruh Asing terhadap Kebijakan liberalisasi Foreign Portofolio Investment}

Dengan tidak adanya ikatan hukum yang kuat atas investor asing terhadap pemerintah sebagai pihak yang menerbitkan Obligasi Negara, maka hal demikian bisa terjadi karena telah diciptakan oleh asing, yaitu melalui adanya tekanan-tekanan atau pengaruh dari pihak luar/asing. Dalam sebagian besar pembuatan kebijakan-kebijakan oleh negara-negara berkembang di dunia, tidak lepas dari pengaruh negara-negara maju, termasuk Indonesia. Washington Consensus (Kesepakatan Wahington)_-sebutan bagi lembaga seperti Bank Dunia, International Monetary Fund (IMF), Departemen Keuangan AS, yang bermarkas di Washington - merupakan lembaga keuangan yang sangat berpengaruh dan sangat terkontaminsi berbagai kepentingan. Konsensus Washington ini didasarkan pada upaya stabilisasi ekonomi lewat jalur kebijakan penyesuaian struktural (Structure Adjustment Programme) yang direkomendasikan oleh organisasi Bretton Woods dan pengambil kebijakan ekonomi pemerintah AS.

Konsensus Washington menekankan kepada pembuatan kebijakan finansial dan makro ekonomi yang hati-hati (prudent), nilai tukar mata uang kompetitif, liberalisasi sektor keuangan dan perdagangan, privatisasi, dan deregulasi. 
Kebijakan-kebijakan ini secara implisit mengajak pemerintah atau negara "menahan diri" untuk tidak ikut campur langsung dalam kegiatan ekonomi, melainkan justru lebih memfokuskan kepada kebijakan moneter, menjamin hak kepemilikan (property rights), dan menyiapkan infrasturktur pendidikan dasar. Dengan AS sebagai sponsor utama, dengan cepat paket kebijakan tersebut mendapatkan sambutan yang luas.

Dari kebijakan Konsensus Washington tersebut terlihat warna dominan perekonomian diarahkan kepada minimalitas peran negara untuk digantikan pasar. Kebijakan deregulasi, misalnya, ditujukan untuk memberi ruang bagi kegiatan ekonomi secara lebih leluasa dengan menghilangkan banyak peraturan yang justru ditengahi disinsentif bagi pertumbuhan investasi. Kebijakan deregulasi ini diperkuat dengan kebijakan liberalisasi, baik di sektor keuangan (foreign portofolio investment) maupun perdagangan, sehingga semakin memacu aktivitasnya. Sedangkan kebijakan privatisasi dan penanaman modal asing (PMA) memiliki peran ganda, di samping menggerus peran negara dalam perekonomian juga dimaksudkan untuk mengikis praktek sektor riil yang selama ini sangat tidak sehat, disortif, dan terkonsentrasi. Akhirnya, kepastian aturan tentang hak kepemilikan (property right) merupakan keniscayaan apabila tujuan yang diinginkan adalah terdapatnya kepastian berusaha bagi setiap pelaku ekonomi, baik domestik maupun asing.

Dalam literatur politik, paket kebijakan penyesuaian struktural biasa disebut dengan istilah Structure Adjusment Programme (SAP). Secara eksplisit, paket Konsensus Washington hendak menghilangkan intervensi negara dalam kegiatan ekonomi, misalnya lewat kebijakan deregulasi dan privatisasi. Dalam perjalanannya, kebijakan itu malah menimbulkan ekses yang cukup banyak, bukan saja dalam lapangan ekonomi tetapi juga di bidang sosial dan politik. Pada titik ini, minimalnya campur tangan negara ternyata tidak menjamin kinerja ekonomi menjadi lebih baik. Inilah kesalahan yang paling fatal yang diproduksi oleh kedua lembaga multilateral tersebut. Konsensus Washington terdiri atas 10 elemen, yang bisa dirangkum menjadi tiga pilar, yakni disiplin anggaran pemerintah, liberalisasi pasar (keuangan), dan privatisasi BUMN. Secara singkat, isi Konsensus Washington yang sering juga disebut sebagai pendekatan Neoliberal adalah:

a. Disiplin fiskal. Pemerintah diminta untuk menjaga agar anggarannya mengalami surplus. Kalaupun terpaksa defisit, tidak boleh melampui $2 \%$ terhadap product domestik bruto (PDB).

b. Memberikan prioritas kepada belanja sektor publik, terutama di sektor pendidikan dan kesehatan, sebagai upaya memperbaiki distribusi pendapatan.

c. Memperluas basis pemungutan pajak agar dapat dibangun struktur penerimaan anggaran yang sehat.

d. Liberalisasi finansial, yakni suku bunga harus dijaga positif secara riil (lebih tinggi daripada laju inflasi) dan hindari kebijakan suku bunga yang mengistimewakan debitur tertentu (preferential interest rates for favored borrowers).

e. Kurs mata uang harus diusahakan kompetitif (tidak terlalu kuat), tetapi kredibel (tidak terlalu lemah).

f. Mendorong liberalisasi perdagangan melalui upaya menghapus restriksi 
kuantitatif (hambatan perdagangan, seperti pengenaan tariff, kuota, dan larangan-larangan lainnya).

g. Menerapkan kesamaan perlakuan antara investasi asing dan investasi domestik sebagai insentif untuk menarik sebanyak mungkin investasi asing langsung.

h. Untuk mendorong kinerja badan usaha milik negara (BUMN), seyogyanya dilakukan privatisasi (penjualan saham ke sektor privat).

i. Pasar harus didorong agar lebih kompetitif melalui serangkaian kebijakan deregulasi dan menghilangkan hambatan atau restriksi bagi para pelaku ekonomi baru.

j. Harus ada perlindungan terhadap property rights, baik di sektor formal maupun informal. ${ }^{41}$

Kebijakan-kebijakan di atas, dalam kebijakan investasi portofolio Indonesia sangat berpengaruh besar, bahkan over tanpa filteralisasi sama sekali. Hal ini ditunjukkan dengan liberalnya arus dana asing (Obligasi Negara) ke Indonesia tanpa hambatan apapun, sehingga dari tahun ke tahun (year on year) Indonesia menjadi salah satu negara emerging market yang empuk bagi negara-negara maju maupun negara berkembang lainnya. Dalam jangka waktu panjang dapat mengakibatkan buble (penggelembungan) dana yang berbahaya bagi negara. Dengan demikian, kebijakan Konsensus Washington telah berhasil mengkolonisasi negara-negara berkembang terutama Indonesia khususnya dalam

$41<$ http://64.203.71.11/kompas-cetak/0609/25/opini/2978827.htm $>$ diakses pada tanggal 2 januari 2011 kebijakan investasi Domestik Portofolio Investment.

Sebuah negara atau lembaga internasional akan bisa menciptakan dominasinya terhadap negara lain melalui penciptaan struktur keuangan. Strange menjelaskan struktur keuangan :

"as the sum of all the arrangement governing the avaibility of credits plus all the faktors determining the terms on which currencies are exchanged for one other".

Artinya bahwa negara ataupun lembaga internasional dapat menciptakan dominasinya terhadap negara lain melalui pemberian kredit atau pinjaman beserta persyaratan-persyaratan yang menyertai pemberian pinjaman tersebut atau yang lebih dikenal sebagai pinjaman yang bersifat conditionalisme.

Dalam konteks ini baik utang luar negeri atau penanaman modal asing sangat diperlukan. Utang luar negeri muncul karena dana dari dalam negeri tidak mampu membiayai proyek yang bisa meningkatkan produk nasional. Oleh karena itu pemerintah mencari jalan keluar dengan meminta bantuan luar negeri, defisit eksternal yang bersifat sementara akan diatasi dengan pembiayaan jangka pendek yang bisa dilakukan dengan penarikan oleh bank sentral fasilitas modal yang disediakan oleh dana moneter internasional (IMF).

Menurut Stiglitz, pentingnya penguatan sistem finansial seharusnya ditujukan untuk lebih dari sekadar upaya menghindari krisis ekonomi. Sistem finansial merupakan otak dari perekonomian dengan mengumpulkan dan mengagregatkan simpanan dari pihakpihak yang tengah mengalami kelebihan sumber daya, serta mengalokasikannya 
pada aktivitas-aktivitas produktif oleh pihak lain.

Sistem finansial yang bekerja baik akan memilih penerima dana yang bisa menggunakan dana tersebut untuk aktivitas yang paling produktif sedangkan sistem finansial yang buruk akan mengalokasikan dana-dana tersebut pada investai yang tidak produktif. Sistem finansial juga harus terus menerus memonitor penggunaan dana untuk memastikan penggunaannya yang lain seperti pengurangan resiko, peningkatan likuiditas, serta penyampaian informasi. Semua fungsi ini penting bagi pertumbuhan modal.

Sistem finansial tidak akan mampu memainkan keseluruhan fungsinya tersebut sendirian. Masalah-masalah seperti ketidaksempurnaan informasi pasar dan tidak lengkapnya perjanjian berpengaruh besar dalam sistem finansial serta acap kali menciptakan tingkat ketidakseimbangan.

Di samping pengaruh di atas, atas dasar kebutuhan ekonomi suatu negara, masing-masing negara cenderung telah tergabung dalam tatanan regionalisme. Indonesia sebagai salah satu negara berkembang keberadaannya termasuk dalam golongan regional ASEAN, sehingga kebijakan-kebijakan yang muncul atas regionalisme di ASEAN telah turut serta dalam mempengaruhi negara-negara anggotanya termasuk Indonesia. Konsep ASEAN-China Free Trade Area (AC-FTA) dan ASEAN Economic Community (AEC) 2015 telah berperan dalam mempegaruhi negara-negara yang tergabung didalamnya termasuk Indonesia dalam hal kebijakankebijakan liberalisasi terutama terkait kebijakan liberalisasi investasi portofolio.

\section{Globalisasi Keuangan: Kompetisi, Inefisiensi, dan Instability}

Era globalisasi dalam beberapa dekade terakhir telah banyak membawa perubahan yang signifikan terhadap kehidupan ekonomi, keuangan, sosial, budaya dan politik dunia. Sebagian negara yang mampu mengambil kesempatan globalisasi tentu dapat menikmati keuntungan, semakin tingginya standar dan kualitas hidup manusia di negaranya. Namun tidak sedikit negara-negara di dunia mengalami krisis yang memakan biaya yang tinggi, akibat proses globalisasi.

Dibidang keuangan, globalisasi telah memaksa perubahan dalam kebijakan pemerintah dan Bank Sentral yang semakin terbuka. Salah satunya dengan kebijakan yang berorientasi pasar dengan menanggalkan restriksi-restriksi yang menghambat mekanisme pasar. Proses globalisasi keuangan telah terjadi di Indonesia sejak dikeluarkannya beberapa paket deregulasi keuangan yang dimulai pada tahun 1983. Kebijakan ini pada awalnya ditujukan untuk mengurangi intervensi pemerintah dalam menstimulasi perekonomian, serta meningkatkan kapabilitas bank untuk memobilisasi dana tabungan dan deposito. Namun, reformasi kebijakan terbesar dalam sejarah perbankan tanah air terjadi ditahun 1988 (PAKTO) dengan ide dasar untuk memberikan kebebasan bagi bank untuk berkompetisi dan berkembang. Kebijakan ini telah mengawali tumbuhnya sektor perbankan dengan pesat.

Dalam kurun waktu 1 (satu) tahun, jumlah pendirian bank meningkat dari 124 bank di tahun 1988, menjadi 158 bank di 
tahun 1991. Peningkatan ini juga dibarengi dengan peningkatan jumlah kantor cabang yang meningkat hingga 1112 unit dalam kurun waktu satu tahun. Selanjutnya, dengan peningkatan bank dan kantor cabang, jumlah dana yang berhasil dihimpun oleh perbankan tanah air juga meningkat pesat. Hal ini sejalan juga dengan pertumbuhan ekonomi nasional yang cukup signifikan.

Deregulasi keuangan pada masa itu telah mendorong peningkatan penggunaan uang (financial deepening) dalam perekonomian domestik. Pada tahun 1996, nisbah M2 terhadap PDB mencapai 0.55, meningkat pesat dari tahun 1988 yang hanya sebesar 0.28. Angka ini tentu menunjukkan tingkat penggunaan uang dalam perekonomian oleh masyarakat sebagai akibat deregulasi sector keuangan tersebut semakin tinggi. Namun patut disayangkan bahwa pertumbuhan yang cepat di sektor perbankan tidak dibarengi dengan regulasi dan supervisi yang baik, sehingga menimbulkan kerentanan dan resiko yang tinggi dalam industri perbankan tanah air dalam kurun waktu 1988-1997. Mengutip pernyataan Santoso (2000) mengatakan:

\section{"In general, deregulation created more fragile operation on banks because of the absence of proper banking supervision. Inability of banks to be immune from foreign exchange and interest rate volatility during crisis is the best example that banks in Indonesia were not equipped with prudential tools with respect to market risk".}

Keterbukaan keuangan akibat paket deregulasi disatu sisi memang telah banyak mensupport keterbatasan dana yang sebelumnya dialami oleh dunia usaha. Sehingga moment deregulasi telah banyak dimanfaatkan perusahaan-perusahaan domestik untuk melakukkan pinjaman luar negeri dalam jumlah yang sangat besar. Namun, karena perbankan sebagai institusi keuangan yang berfungsi sebagai intermediasi utama dalam proses tersebut, maka ketidakmampuan pembayaran perusahaan juga menjadi resiko bagi kebangkrutan bank. Steven, mengatakan:

"At its heart, the Asian crisis was a banking crisis brought on by banks and their customers taking on too much foreign currency risk. No doubt macroeconomic policies were not always perfect, but the real problems were in the financial structure more than the macroeconomic settings."

Krisis keuangan yang dialami oleh negara-negara di Asia secara apik dirangkum dalam Mc kinnon ${ }^{42}$, yang memaparkan model sindrom "Overborrowing" atau pinjaman yang berlebihan ditengah-tengah reformasi dan liberalisasi ekonomi. Ia menjelaskan bagaimana tingginya aliran modal masuk (high capital inflow) pada akhirnya membahayakan (jeopardized) pada proses reformasi itu sendiri. Dalam penelitiannya Mc Kinnon and Pill memfokuskan pada "moral hazard" didalam sistem perbankan domestik akibat adanya jaminan deposito oleh pemerintah sehingga mendorong adanya "international overborrowing".

Pengembangan model krisis keuangan dilanjutkan dengan menambahkan resiko "currency risk" dalam model "overborrowing" secara eksplisit. Dalam model "overborrowing syndrome" moral

42 McKinnon, R. I., and Pill, H., 'Credible Economic Development and over-Borrowing,' American Economic Review, 87 (2), 1997, hlm. 189-193. 
hazard mendorong bank domestik untuk meminjam ke luar negeri dalam jumlah yang besar, hal ini disebabkan karena bank domestik mengganggap pemerintah melakukkan garansi penerapan nilai tukar yang tetap untuk mengurangi payment risk atau resiko pembayaran.

Potensial krisis dalam ekonomi yang mengalami "overborrowing syndrome" terjadi karena adanya moral hazard dalam sistem perbankan dan pasar keuangan serta kurangnya control terhadap aliran modal yang masuk dan keluar. Dengan pinjaman yang tinggi butuh pengembalian yang tinggi, namun karena macroeconomic outcome dari program reformasi memberikan return yang lebih rendah dari yang seharusnya dibayarkan. Maka yang terjadi adalah credit risk. Sehingga "only a lucky draw" yang akan menghindari ekonomi dari krisis ekonomi.

Dengan adanya resiko nilai tukar, bank akan mengalami dua resiko utama. Pertama, resiko kredit dan kedua adalah resiko nilai tukar yang disebabkan oleh pinjaman luar negeri yang tidak dilindungi atau unhedge borrowing. Permasalahan yang rumit ketika semua pinjaman bank jatuh tempo pada waktu yang bersamaan, dan tentunya pada saat itu kebutuhan akan mata uang asing akan lebih banyak. Keadaan ini tentunya akan mendorong rupiah terdepresiasi, karena sebagian besar bank akan menjual rupiahnya untuk mata uang asing. Devaluasi pada mata uang domestik akibat terbatasnya cadangan bank sentral inilah, yang pada akhirnya memperbesar pinjaman luar negeri bank, dan menguras modal bank yang pada akhirnya bank terjebak dalam keadaan insolvent atau kebangkrutan. ${ }^{43}$

43 Model krisis keuangan secara lengkap dipaparkan oleh Mc Kinon dalam beberapa
Paparan diatas tentu menyadarkan kita, bahwa deregulasi dan globalisasi keuangan (liberalisasi keuangan) tanpa dibarengi dengan regulasi dan supervisi yang kuat hanya akan membawa malapetaka bagi perekonomian domestik. Di Indonesia, biaya untuk melakukkan recovery di sektor keuangan tentu jumlahnya tidak sedikit. Secara umum, biaya krisis di Indonesia mencapai 50-60\% dari total GDP secara umum. Suatu angka yang sangat fenomenal, bahwa krisis yang diawali dengan krisis nilai tukar yang dilanjutkan dengan krisis perbankan dan krisis ekonomi telah banyak menguras sumber-sumber yang produktif dari negeri ini.

Perbankan, sebagai sektor yang dianakemaskan dalam setiap perekonomian, telah banyak menikmati proses liberalisasi keuangan (foreign portofolio investment) dengan memanfaat-kan sumber-sumber dana murah dari luar negeri. Hal ini tentu saja merupakan peluang keuntungan yang meningkatkan keuntungan mereka. Namun, kurangnya supervisi dan kesadaran pentingnya perlindungan terhadap resiko, menyebabkan sektor ini sangat rentan terhadap external shock.

Di sisi lain, globalisasi keuangan (liberalisasi keuangan) yang ditandai dengan semakin meningkatnya jenis-jenis asset keuangan di pasar keuangan domestik maupun luar negeri, telah mendorong aktvitas perbankan dari yang sifatnya tradisional ke aktivitas yang sifatnya nontradisional. Selanjutnya, dengan adanya

tulisannya. Salah satunya adalah McKinon, R. and Huw Pill., "Exchange rate Regimes for Emerging Markets: Moral Hazard and International Overborrowing", Oxford Review of Economic policy, 1999, hlm. 23-64. 
proses globalisasi keuangan, perbankan domestik akan semakin terdesak dengan adanya kompetisi dari pemain asing. Hal ini selain akan mengurangi market share dan keuntungan bank, juga berindikasi mendorong aktivitas perbankan ke transaksi yang sifatnya spekulatif dengan niat mendapatkan keuntungan yang tinggi, meski resikonya juga tinggi.

Tentu saja, perlu dianalisis lebih dalam bagaimana logika globalisasi keuangan (liberalisasi keuangan), khususnya pada foreign portofolio investment mempengaruhi aktivitas perbankan tanah air. Pertama, dengan semakin tingginnya liberalisasi keuangan (foreign portofolio investment), maka sumber instabilitas keuangan akan semakin tinggi. Hal ini tentu saja akan mempengaruhi market value dari sisi aset dan liabilitas bank. Sebagai contoh, bagaimana capital outflow aliran modal keluar yang meningkat semisal akibat sentimen negatif investor terhadap perekonomian domestik. Dalam hal ini, aliran modal keluar tentu akan menyebabkan nilai tukar domestik akan semakin terdepresiasi, dan tentu memaksa kebijakan moneter yang cenderung ketat dengan implikasi suku bunga yang tinggi. Dalam konteks ini, fenomena tersebut telah menyebabkan perbankan akan menghadapi dua resiko sekaligus dalam jangka pendek, yaitu: resiko suku bunga dan resiko nilai tukar. $^{44}$

44 Dalam tulisannya, "Capital Market Liberalization, Economic Growth and Instability", Joseph E. Stiglitz memaparkan bagaimana asumsi neo klasik yang memahami uang sama seperti komoditas lainnya, sehingga beranggapan liberalisasi keuangan sama pentingnya dengan liberalisasi ekonomi. Dalam pandangannya, Stiglitz berpandangan bahwa uang tidaklah sama dengan barang dan jasa, sehingga treatmentnya pun harus berbeda. Ia beranggapan bahwa fungsi pasar keuangan yang
Kedua, dengan semakin tingginya globalisasi keuangan khususnya melalui foreign portofolio investment, maka pengenalan terhadap jenis-jenis aset keuangan yang baru akan semakin tinggi. Hal ini berkaitan dengan pilihan-pilihan aset keuangan yang menggiurkan bagi sektor perbankan, baik yang sifatnya hanya sebagai dealer atau penjual aset keuangan kepada masyarakat hingga yang sifatnya sebagai player atau bank bertransaksi langsung. Tentu saja dengan semakin enjoynya sektor perbankan untuk mendistribusikan dananya pada aset-aset keuangan "derivatif" maka peluang untuk menginvestasikkannya dalam bentuk kredit produktif (modal kerja dan investasi) akan semakin berkurang.

Ketiga, dengan semakin tingginya globalisasi keuangan khususnya melalui foreign portofolio investment, yang juga berarti semakin banyaknya pemain-pemain asing yang masuk dalam industri perbankan sudah pasti akan menggeser market share perbankan, sehingga pada akhirnya akan mendorong bank untuk mencari sumbersumber investasi baru. Salah satunya yang less cost, dan menjanjikan keuntungan yang tinggi meski resikonya tingginya adalah dengan bergantung pada transaksi derivatif.

Dalam konteks yang terakhir, ada fenomena baru meningkatnya jumlah asing di Indonesia dalam beberapa tahun terakhir, yakni Indonesia meliberalisasi juga institusi perbankan, dengan menjualnya ke asing di samping telah liberalisasi pada sisi kebijakannya, yakni melalui membeli dan menjual foreign portofolio investment.

dianggap berfungsi “diversifikasi”bagi asset keuangan sehingga mendorong stabilitas, dianggapnya tidak berjalan secara optimal. Hal ini utamanya disebabkan karena sifat instrument keuangan pasar modal yang unstable dan berjangka pendek. 
Kebijakan liberalisasi perbankan nasional ini dimulai pada masa pemerintahan presiden Habibie, yakni ketika diterbitkannya Undang-Undang Nomor 10 tahun 1998 tentang Perbankan (perubahan atas UU Perbankan sebelumnya) yang adalah lebih akomodatif terhadap kebijakan intermadiasi. Undang-undang terbaru ini secara substansial sangat eksplisit di dalam mendorong salah satu agenda Washington Consensus, yaitu liberalisasi sektor keuangan dan perdagangan. Lebih parah lagi, semangat liberalisasi ini dilakukan dengan keblabasan (over), tanpa penyiapan jaring pengaman dari liberalisasi, terutama terkait dengan manajemen resiko.

Bab umum dari penjelasan UndangUndang Nomor 10 tahun 1998 menyebutkan: "Upaya liberalisasi di bidang perbankan dilakukan sedemikian rupa sehingga dapat sekaligus meningkatkan kinerja perbankan nasional. Oleh karena itu, perlu diberikan kesempatan yang lebih besar kepada pihak asing untuk berperan serta dalam memiliki bank nasional sehingga tetap terjadi kemitraan dengan pihak nasional."

Jiwa liberalisasi ini, kemudian diaktualisasikan ke dalam Pasal 22 ayat $1 \mathrm{~b}$ yang membebaskan warga negara asing dan atau badan hukum asing untuk mendirikan Bank Umum secara kemitraan dengan warga negara atau badan hukum Indonesia. Kemudian ditegaskan kembali dalam Pasal 6 ayat 2 yang membebaskan warga negara asing dan atau badan hukum asing untuk membeli saham Bank Umum secara langsung dan atau melalui bursa efek.

Dengan aturan di atas, pihak asing bisa memiliki hingga 99\% saham bank di Indonesia. Ini jauh lebih tinggi dari komitmen Indonesia di WTO yang pada awalnya adalah 49\%, lalu dinaikkan menjadi 51\%. Indonesia bahkan lebih liberal dari negara-negara Amerika Serikat, Kanada, Australia, Singapura, Thailand dan sebagainya yang menerapkan pembatasan kepemilikan asing dalam sektor perbankannya. Selain dampak dari UndangUndang Perbankan yang sangat liberal ini, saat ini 6 dari 10 bank terbesar di Indonesia sudah dimiliki pihak asing dengan kepemilikan mayoritas. ${ }^{45}$

Tentu pertanyaannya adalah apakah tingginya jumlah pemain asing di industri perbankan dapat meningkatkan efisiensi dalam sistem keuangan akibat semakin kompetitifnya pasar perbankan tanah air?, ataukah pemain asing hanya sebagai sumber instabilitas baru bagi sistem keuangan domestik?. Mudah saja untuk berhipotesis untuk menjelaskan fenomena. Meski analisis ini masih terlalu dini untuk diambil sebagai kesimpulan, namun hasil empiris yang ditemukan oleh Lapavitsas ${ }^{46}$ menjelaskan fenomena meningkatnya pemain asing dalam pasar domestik negaranegara berkembang telah mengancam instabilitas perekonomian domestik. Analoginya adalah, dengan keterbatasan informasi berkaitan dengan "hambatan budaya" atau cultural barrier, pemain asing masuk ke pasar perbankan dengan memanfaatkan analisis "arm-length" dengan memanfaatkan komputerisasi IT (Teknologi Informasi) untuk menganalisis kelayakan. Hal ini berimplikasi pada jenis aset atau investasi yang ditawarkan pemain asing pada masyarakat domestik, yang cenderung mengarah pada pinjaman atau kredit yang sifatnya konsumtif dengan penggunaan kartu kredit. Dengan

45 Amien Rais, Agenda Mendesak Bangsa: Selamatkan Indonesia!, Yogyakarta, PPSK Press, 2008, hlm. 185-186.

${ }^{46}$ Costas Lapavitsas, P. L. D. S., 'Globalization and Contemporary Banking: On the Impact of New Technology,' Political Economy, 2007, Page 1 of 26. 
penggunaan IT yang maju, proses studi kelayakan dan monitoring klien dalam jumlah yang besar akan semakin mudah untuk dilakukkan dengan biaya yang rendah. ${ }^{47}$

Untuk menjelaskan fenomena Bank Asing di tanah air, Bank Indonesia masih belum secara eksplisit merinci aktivitas kegiatannya di pasar keuangan domestik khususnya dalam membagi jenis kredit dan aset yang dimiliki oleh Bank Asing. Sehingga keterbatasan untuk menganalisis peran bank asing tersebut di dalam industri perbankan tanah air akan semakin sulit. Namun, sederhana saja, media massa (elektronik maupun yang paper based) telah gencar mensosialisasikan produkproduk keuangan bank asing yang sebagian besar adalah kartu kredit bukan informasi terkait kredit Usaha Mikro Kecil Menengah (UMKM) bagi masyarakat.

47 Implikasi masuknya bank-bank asing di negara berkembang menimbulkan kontroversi dan pro kontra. Penelitian terbaru yang dilakukkan oleh World Bank di tahun 2007 http://go.worldbank.org/BTI7JEX1S0)

"Foreign bank participation and crises in developing countries" yang ditulis oleh Robert Cull et.al. menjelaskan bahwa peluang terjadinya krisis erbankan terjadi lebih besar pada pasar keuangan yang didominasi oleh perbankan asing. Pendapat yang pro terhadap masuknya Bank Asing dalam pasar domestik mengedepankan alasan meningkatnya supply dana atau akses kredit dalam perekonomian, adopsi teknologi yang tinggi, alasan efisiennya bank asing (karena mudah untuk mencari tambahan dana di pasar keuangan internasional) dalam Gormley, T. A. (2007), "Banking Competition in Developing Countries: Does Foreign Bank Entry Improve Credit Access?"

\section{Kebijakan Perbankan terhadap Pembelian Foreign Portofolio Investment}

Kebijakan perbankan pada dasarnya difokuskan pada kesinambungan upaya pelaksanaan program restrukturisasi perbankan. Hal ini dilakukan melalui, pertama, program penyehatan perbankan yang meliputi penjaminan pemerintah bagi bank umum dan Bank Perkreditan Rakyat (BPR), rekapitalisasi bank umum dan restrukturisasi kredit perbankan; kedua, program pemantapan ketahanan sistem perbankan yang meliputi pengembangan infrastruktur perbankan, peningkatan good corporate governance, serta penyempurnaan pengaturan dan pemantapan sistem pengawasan bank; ketiga, program pemulihan fungsi intermediasi perbankan, terutama melalui upaya mendorong penyaluran kredit di sektor Usaha Mikro, Kecil dan Menengah (UMKM). ${ }^{48}$

Dalam Undang-Undang Nomor 10 Tahun 1998 tentang Perbankan disebutkan bahwa, fungsi perbankan nasional adalah sebagai penghimpun dan penyalur dana masyarakat. Oleh karena itu, kebijakan perbankan yang paling utama adalah segala hal yang berkaitan dengan usaha menghimpun dana dan berikut penyalurannya kepada masyarakat. Namun demikian, berdasarkan jenisnya, yang meliputi Bank Umum dan Bank Perkreditan Rakyat (BPR) sebagaimana disebutkan dalam pasal 5 (lima) UndangUndang Perbankan, maka kebijakan perbankan juga meliputi sebagaimana pasal 6 butir (d) sebagai berikut:

\section{Usaha Bank Umum meliputi:}

${ }^{48}$ Laporan Tahunan Bank Indonesia 2002, hlm. 141 
d. membeli, menjual atau menjamin atas risiko sendiri maupun untuk kepentingan dan atas perintah nasabahnya:

1. surat-surat wesel termasuk wesel yang diakseptasi oleh bank yang masa berlakunya tidak lebih lama daripada kebiasaan dalam perdagangan surat-surat dimaksud;

2. surat pengakuan hutang dan kertas dagang lainnya yang masa berlakunya tidak lebih lama dari kebiasaan dalam perdagangan surat-surat dimaksud;

3. kertas perbendaharaan negara dan surat jaminan pemerintah;

4. Sertifikat Bank Indonesia (SBI) ;

5. obligasi;

6. surat dagang berjangka waktu sampai dengan 1 (satu) tahun;

7. instrumen surat berharga lain yang berjangka waktu sampai dengan 1 (satu) tahun;

\section{Berdasarkan Undang-Undang}

Perbankan di atas, maka secara eksplisit bermakna menjadi bahwa fungsi perbankan nasional adalah menghimpun dan menyalurkan dana ke masyarakat serta membeli, menjual, dan menjamin atas segala resiko atas investasi portofolio (foreign portofolio investment) baik jangka panjang, menengah, maupun pendek. Namun demikian, keberadaan bank dalam skala nasional (asal mula politik pembentuknya) adalah menghimpun dan menyalurkan dana kepada masyarakat guna mendukung pembangunan ekonomi nasional dalam rangka menyejahterakan rakyat. Oleh karena itu, sudah selayaknya kebijakan intermediasi perbankan kepada masayarakat adalah hal yang paling utama daripada fungsi turunan perbankan lainnya sebagaimana termaktub dalam pasal 6 terutama butir (d). Kebijakan pengembangan UMKM melalui lancarnya kredit, harus menjadi prioritas utama sebagai aktualisasi dari fungsi utama perbankan nasional. Namun demikian, perhatian pemerintah melalui perbankan dalam aktualisasi kebijakannya seringkali tidak sebanding dengan aturan tertulisnya. Hal tersebut dapat dilihat dari kuantitas perkembangan dana menunjukkan ketimpangan antara Obligasi Negara/Pemerintah dengan dana yang dikucurkan untuk pengembangan UMKM melalui kredit.

Dalam hal kebijakan perbankan dalam pembelian foreign portofolio investment Obligasi Negara/Pemerintah, pemeritah telah melakukan pembelian surat-surat berharga (SBN) jenis obligasi negara/pemerintah sebagaimana yang telah dijelaskan pada bab ke-2 penelitian ini, yang meliputi pembelian Surat Utang Negara (SUN) yang berupa Surat Perbendaharaan Negara (SPN), Obligasi Ritel Negara (ORI), dan Surat Berharga Syari'ah Negara (SBSN) baik melalui pasar perdana (Departemen Keuangan RI) maupun pasar sekunder (Pasar modal).

\section{Pembahasan}

\section{Implikasi terhadap Kebijakan Perbankan secara Umum}

Berdasarkan beberapa akibat atau ancaman besar yang dipaparkan sebelumnya, "globalisasi keuangan dalam bentuk liberalisasi foreign portofolio investment, maka kekuatan sistem keuangan domestik akan semakin berkurang akibat pengaruh asing dalam hal intervensi kebijakan, sebagaimana telah dijelaskan pada bab sebelumnya. Pemerintah justru memperbanyak porsi legalisasi terhadap kebijakan liberalisasi foreign portofolio investment sebagai manifestasi kebijakan Washington Concensus oleh Barat melalui IMF dan World Bank. 
Hal ini mengakibatkan daya tarik pemerintah maupun institusi keuangan (perbankan) untuk melakukan instruksi tersebut, sehingga mengakibatkan lumpuhnya fungsi vital perbankan. Keadaan ini akan semakin parah, khususnya di negara-negara berkembang seperti Indonesia yang menggantungkan sebagian besar sumber dananya dari intermediasi perbankan. Sehingga pada akhirnya ancaman terhadap stabilitas sistem keuangan, dan dampaknya secara negatif terhadap perekonomian dan pembangunan ekonomi juga akan meluas.

Sebagaimana penjelasan di atas, bahwa terkontaminasinya domestik portofolio investment, mengakibatkan ketertarikan yang besar oleh pemerintah dan institusi keuangan (perbankan), sehingga berakibat perbankan sudah tidak lagi menjadi agent of development yang strategis. Jika fungsi vital intermediasi perbankan sudah lumpuh, institusi mana yang akan menggantikan perannya? Apakah institusi tersebut mampu menyediakan biaya transaksi dan resiko yang kecil? Apakah institusi ini mampu menyediakan fungsi intermediasi berkaitan dengan pembagian resiko "risk sharing" dan mengurangi asytemric information?. Hal inilah yang seharusnya menjadi perhatian policy maker untuk mencari solusi terhadap kelumpuhan yang mengancam industri perbankan tanah air.

Meminjam kata yang digunakan Mc Kinon, mungkin hanya "lucky draw" saja yang dapat menyelematkan industri perbankan tanah air. Indikasi kesehatan perbankan secara mikro, yang ditandai dengan tingginya ekspansi kredit konsumtif, transaksi derivatif, obligasi negara/pemerintah maupun korporasi dan fee based income tentu menjelaskan pergeseran fungsi vital perbankan secara tradisional, yang seharusnya memfokuskan diri pada pembiayaan pinjaman bagi dunia usaha yang produktif untuk menyokong pembangunan ekonomi.

Bagi perusahaan besar, pencarian sumber dana-dana lain mungkin akan mudah untuk dilakukkan jika fungsi vital intermediasi perbankan sudah lumpuh. Hal ini dilakukkan dengan mengeluarkan surat berharga obligasi ataupun saham. Namun bagi usaha kecil dan menengah, proses tersebut akan semakin sulit untuk dilakukkan. Sehingga, lumpuhnya fungsi vital intermediasi perbankan sedikit banyak akan menyulitkan tambahan modal kerja dan investasi bagi kebutuhan ekspansi bisnis mereka. Belum lagi, dominasi UMKM yang sangat tinggi di negara berkembang seperti Indonesia sudah pasti akan semakin melarat dengan lumpuhnya fungsi vital intermediasi perbankan. Secara lebih rinci beberapa implikasi terhadap pemberian kredit UMKM akan dijelaskan sebagai berikut.

\section{Implikasi Politik terhadap Kebijakan Perbankan dalam Pemberian Kredit UMKM}

Dengan melihat kebijakan-kebijakan pemerintah pada masa/era kepemimpinan presiden Megawati Soekarno putrid hingga Susilo Bambang Yudhoyono, maka kebijakan secara substansi memiliki peran yang sangat signifikan terhadap pengembangan UMKM khususnya pada permasalahan kredit UMKM. Artinya, perhatian negara/pemerintah melalui sektor perbankan sebagai lembaga intermediasi sangatlah besar. Namun demikian, yang menjadi pertanyaan adalah, apakah hal tersebut equivalen (sejalan) dengan kebijakan yang ada?. Dengan melihat kenyataan, pertanyaan penting namun sederhana untuk menggambarkan perkembangan kebijakan perkreditan 
Indonesia adalah "mengapa dana yang disimpan di sektor perbankan begitu banyak, sementara kredit yang disalurkan ke dunia usaha (sektor riil) sejak krisis ekonomi 1997/98 hingga sekarang kenyataannya sedikit?" Pertanyaan berikutnya tentu dengan sendirinya, "kenapa demikian, apakah sektor perbankan yang enggan menyalurkan dananya ke dunia usaha, mereka lebih suka menabung di Bank Indonesia (BI), atau dunia usaha yang enggan meminjam uang dari perbankan?".

Secara politis, pertanyaan tersebut di atas tidak muncul begitu saja, namun terjadi akibat konstruksi sosial yang menggambarkan peran negara yang semakin lemah. Kebijakan perbankan dalam hal intermediasi merupakan kebijakan turunan makro atas kebijakan yang dikeluarkan pemerintah melalui Kementerian koperasi dan UKM, namun demikian substansi UU Perbankan tidak sinkron dengan UU yang berkaitan dengan UMKM. Mengapa demikian?. Adanya moral hazard aktor-aktor negara baik internal maupun eksternal telah menjadi pemicu deviasisasi kebijakan ini.

Hal ini mengakibatkan fenomena teknis yang dapat digambarkan walaupun belakangan ini BI rate (atau Sertifikat Bank Indonesia/ $/ \mathrm{SBI}^{49}$ ) cenderung menurun terus, tetapi kelihatannya arus kredit perbankan ke sektor riil tidak meningkat pesat. Hal ini menimbulkan pertanyaan berikut: "apakah Bank Indonesia (BI) dengan menurunkan suku bunganya bisa mendorong perbankan untuk meningkatkan penyaluran kredit ke dunia usaha?". Berikut perkembangan

49 Sertifikat Bank Indonesia (SBI) adalah Surat berharga sebagai pengakuan utang berjangka waktu pendek dalam mata uang rupiah yang diterbitkan oleh Bank Indonesia dengan sistem diskonto. kebijakan perbankan terkait pemberian kredit UMKM sebagai implikasi atas kebijakan foreign portofolio investment, dilihat dari perspektif Perbankan sebagai regulator dan dari perspektif dunia usaha/pelaku UMKM sebagai konsumen, sebagai manifestasi atas politisasi kebijakan perbankan sebagai berikut.

\section{a. Dilihat dari Sisi Perspektif Perbankan}

Berdasarkan data Biro Pusat Statistik (BPS), dari Januari hingga Oktober 2006 pendapatan perbankan mencapai Rp 14,59 triliun atau naik $122 \%$ dari sebesar $\mathrm{Rp} 6,58$ triliun pada periode yang sama tahun 2005, dan laba bersih perbankan meningkat sekitar 13\%. Selanjutnya, laba bersih perbankan selama tahun 2006 tercatat sebanyak Rp. 28,33 triliun, atau telah mengalami suatu pertumbuhan sebesar $16 \%$ jika dibandingkan dengan jumlah keuntungan pada satu tahun sebelumnya yakni Rp 25 triliun. Akan tetapi, pertumbuhan laba yang cukup signifikan itu lebih didorong oleh besarnya pendapatan bunga dari Sertifikat Bank Indonesia (SBI) serta Surat Utang Negara (SUN) dan besarnya margin (keuntungan) antara bunga kredit dan bunga dana (deposito), bukan oleh ekspansi kredit. ${ }^{50}$ Berdasarkan Statistik Perbankan Indonesia Desember 2006, pendapatan perbankan dari bunga kredit mengalami suatu pertumbuhan sebesar 24\% dari $\mathrm{Rp} 84,22$ triliun pada tahun 2005 menjadi Rp 104,79 triliun pada tahun lalu. Besarnya margin bunga itu terjadi karena perbankan cenderung

\footnotetext{
${ }^{50}$ Menurut data BI, pada akhir tahun 2005, selisih suku bunga antara deposito 1 bulan dan kredit konsumsi sebesar 640 basis poin. Namun pada akhir 2006, selisihnya melebar menjadi 860 basis poin. Suku bunga deposito 1 bulan turun dari $10,4 \%$ menjadi $9 \%$, sedangkan suku bunga kredit konsumsi justru meningkat dari $16,8 \%$ ke hampir $18 \%$ (Kompas, 23 Februari 2007).
} 
mempertahankan suku bunga kredit meskipun suku bunga dana terus menurun. Namun sekarang pertanyaannya, apakah perbankan akan tetap mempertahankan suku bunga kreditnya walaupun suku bunga BI (Sertifikat Bank Indonesia) cenderung menurun terus, yang sempat mencapai sekitar 12,75\% Maret 2006 merosot ke $10,25 \%$ November 2006, dan turun sekitar $6,5 \%$ hingga sampai sekarang 2010. Secara teori tentu penurunan ini akan mengurangi keinginan perbankan menyimpan dananya di SBI (atau/dan di SUN/Obligasi Negara), dan pada akhirnya akan membuat suku bunga di sektor keuangan menurun. Namun, nampaknya bank-bank nasional tetap merasa lebih untung menyimpan dana mereka dalam bentuk Sertifikat Bank Indonesia (atau SUN/Obligasi Negara) ketimbang menyalurkan kredit, terutama ke dunia usaha. Pada akhir Oktober 2006 posisi dana perbankan yang ditempatkan pada Sertifikat Bank Indonesia mencapai Rp 136,56 triliun atau meningkat hampir Rp 110 triliun dari posisinya pada akhir Oktober 2005. Menurut Kompas (Selasa, 27 Februari, 2007), per Februari 2007, SBI berada di posisi Rp 237 triliun. $^{51}$

Jadi, isu sebenarnya di sini adalah menguji kembali teori konvensional mengenai korelasi positif antara suku bunga di bank sentral dengan suku bunga di pasar uang, atau teori moneter yang menyatakan bahwa kebijakan moneter ekspansif ditandai dengan meningkatnya suplai uang di

${ }^{13}$ Bahkan menurut Burhanuddin Abdullah (dikutip dari Kompas, Selasa, 27 Februari 2007), nilai SBI bisa mencapai Rp 300 triliun pada akhir tahun 2007. Menurutnya, kondisi tersebut dapat terjadi karena terdapat sejumlah potensi penambahan SBI yang cukup signifikan tahun ini. Potensi tersebut, antara lain bunga SBI sebesar Rp 25 triliun, bunga SUN Rp 65 triliun, dan aliran modal masuk sekitar Rp 15 triliun. masyarakat yang diawali dengan menurunnya suku bunga di bank sentral. Sebaliknya, kebijakan moneter yang kontraktif ditandai dengan berkurangnya jumlah uang yang beredar di masyarakat yang diawali dengan suku bunga meningkat.

Gambar 1: Perkembangan Suku Bunga SBI 1 bulan (\%)

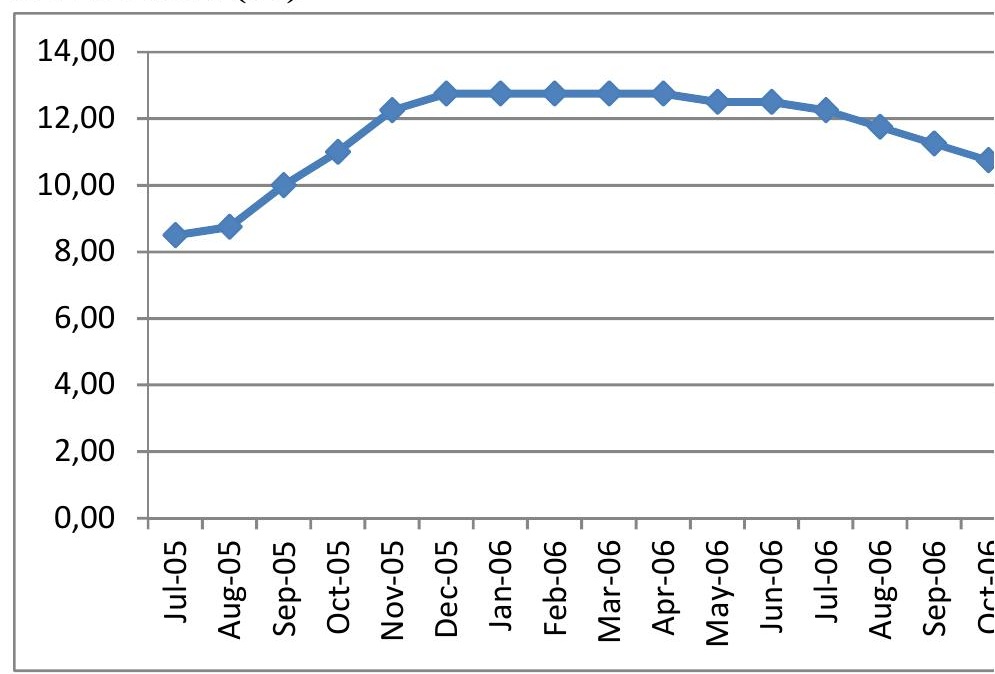

Gambar 2: Perkembangan Suku Bungan SBI, Deposito dan Pinjaman Antar Bank (\%)

\begin{tabular}{|c|c|c|c|}
\hline Sertifikat Bank Indonesia & $\mathbf{2 0 0 4}$ & $\mathbf{2 0 0 5}$ & $\mathbf{2 0 0 6}$ \\
\hline 1 Bulan & 7,43 & 12,75 & 9,75 \\
\hline 3 Bulan & - & - & - \\
\hline 6 Bulan & - & - & - \\
\hline
\end{tabular}

Sumber: Bank Indonesia

Selanjutnya, jika dilihat dari perbedaan antara suku bunga pinjaman dan suku bunga deposito, hasil penelitian World Economic Forum (WEF) berdasarkan data sekunder 2005 atau yang paling akhir yang ada pada saat ini (2010) menunjukkan bahwa dari 125 negara, posisi Indonesia sangat rendah yakni pada peringkat 66 dengan poin 6.0. Indonesia juga paling rendah di dalam kelompok ASEAN, terkecuali Kamboja yang berada pada 
peringkat 113 . Yang masuk 10 besar adalah termasuk Belanda, Jepang, dan Inggris.

Tabel 1: Rata-rata perbedaan suku bunga antara Pinjaman dan Deposito di dalam The Global Competitiveness Report 2006-2007*

\begin{tabular}{|c|l|c|}
\hline $\begin{array}{c}\text { Peri } \\
\text { ngk } \\
\text { at }\end{array}$ & $\begin{array}{c}\text { Nega } \\
\text { ra }\end{array}$ & $\begin{array}{c}\text { D } \\
\text { at } \\
\text { a }\end{array}$ \\
\hline & Belan & 0 \\
& da & 4 \\
& Jepan & 1, \\
& g & 4 \\
& Inggri & 1, \\
& s & 4 \\
& Austr & 1, \\
1 & ia & 5 \\
2 & Luxe & 1, \\
3 & mbou & 7 \\
4 & rg & 1, \\
5 & Korea & 9 \\
6 & Selata & 2, \\
7 & n & 1 \\
8 & Portu & 2, \\
9 & gal & 1 \\
10 & Span & 2, \\
20 & yol & 2 \\
25 & Norw & 2, \\
35 & egia & 3 \\
36 & Taiw & 3, \\
49 & an, & 0 \\
51 & China & 3, \\
54 & Mala & 3 \\
66 & ysia & 3, \\
113 & China & 9 \\
& Vietn & 3, \\
& am & 9 \\
& Thail & 4, \\
& and & 6 \\
& Filipi & 4, \\
& India & 4, \\
Singa & 9 \\
\hline
\end{tabular}

Keterangan: * data sekunder 2005 atau paling akhir yang tersedia. Sumber: World Economic Forum (2006).

Kembali ke salah satu pertanyaan di atas yakni kenapa suku bunga SBI menurun atau margin antara suku bunga SBI dan suku bunga deposito kecil tetapi penyaluran kredit ke dunia usaha tetap kecil. Pertumbuhan kredit hanya sekitar 10,5\% pada akhir Oktober 2006 dan 30,51\% pada akhir tahun 2008. Pertumbuhan ini tidak saja lebih rendah dari pertumbuhan tahun 2005 yang mencapai $17,5 \%$, tetapi juga lebih rendah dari pertumbuhan dana pihak ketiga (DPK) yang tumbuh $15,5 \%$ dalam 10 bulan pertama tahun 2006. Namun demikian, perlu diakui bahwa sejak tahun 1999 jumlah kredit yang disalurkan menunjukkan peningkatan terus. Hal ini juga terrefleksi oleh peningkatan dari rasio pinjaman-deposito atau LDR dari $36 \%$ ke 65 \% Juli 2006.

Tabel 2: Penyaluran Kredit Perbankan (Triliun)

\begin{tabular}{|l|c|c|c|}
\hline $\begin{array}{c}\text { Ta } \\
\text { hun }\end{array}$ & $\begin{array}{c}\text { Depo } \\
\text { sito }\end{array}$ & $\begin{array}{c}\text { Kre } \\
\text { dit }\end{array}$ & $\begin{array}{c}\text { L } \\
\text { D } \\
\text { R } \\
( \\
\end{array}$ \\
& & & \\
& & & ) \\
\hline 199 & 358 & 378 & 10 \\
7 & 573 & 487 & 6 \\
199 & 626 & 225 & 85 \\
8 & 720 & 269 & 36 \\
199 & 809 & 308 & 37 \\
9 & 836 & 410 & 38 \\
\hline
\end{tabular}




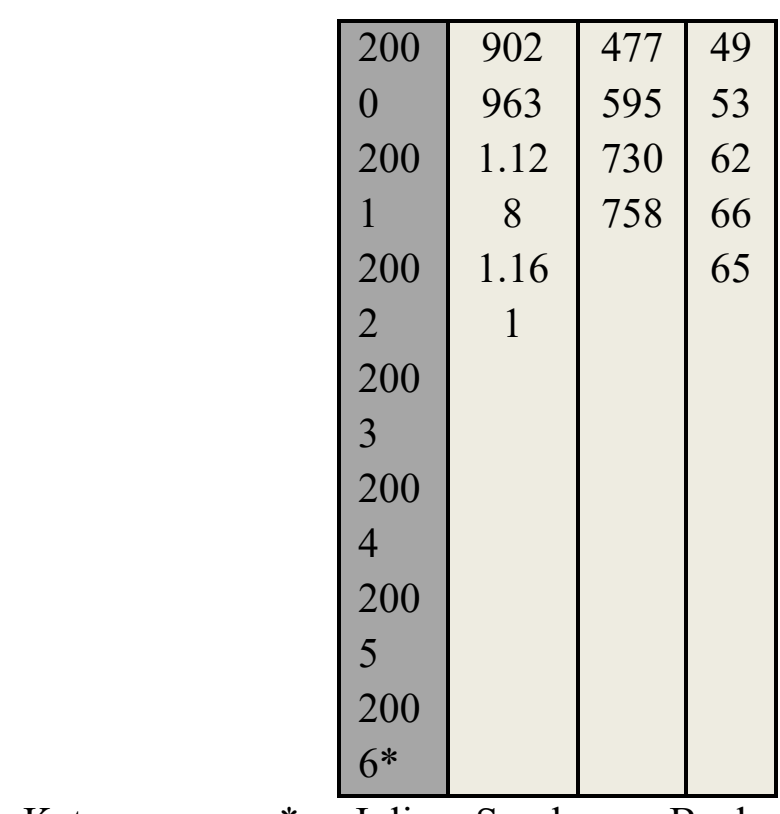

Keterangan:

Indonesia

Memang dilihat dari perspektif global berdasarkan country credit rating, menurut hasil survei dari World Economic Forum (WEF), posisi Indonesia sangat buruk. Dari 125 negara yang diteliti Indonesia berada pada peringkat ke 78 ; juga paling rendah dibandingkan negara-negara anggota ASEAN lainnya. Dalam indikator ini, 10 besar didominasi oleh negara-negara industri maju.

Tabel 3: Country Credit Rating di dalam The Global Competitiveness Report 20062007*

\begin{tabular}{|c|l|c|}
\hline $\begin{array}{c}\text { Peri } \\
\text { ngk } \\
\text { at }\end{array}$ & $\begin{array}{c}\text { Nega } \\
\text { ra }\end{array}$ & $\begin{array}{c}\text { D } \\
\text { at } \\
\text { a }\end{array}$ \\
\hline 1 & Swiss & 9 \\
2 & Norw & 5, \\
3 & egia & 5 \\
4 & Finla & 9 \\
5 & ndia & 4, \\
6 & Inggri & 6 \\
7 & s & 9 \\
8 & Denm & 4, \\
9 & ark & 2 \\
10 & Luxe & 9 \\
17 & mbou & 4, \\
\hline
\end{tabular}

\begin{tabular}{|c|c|c|}
\hline 37 & $\mathrm{rg}$ & 1 \\
\hline 46 & Swed & 9 \\
\hline 55 & en & 4, \\
\hline 73 & Belan & 0 \\
\hline 75 & $\mathrm{da}$ & 9 \\
\hline 78 & Amer & 3 , \\
\hline 111 & ika & 7 \\
\hline & Serik & 9 \\
\hline & at & 3 \\
\hline & Kana & 6 \\
\hline & $\mathrm{da}$ & 9 \\
\hline & Singa & 3 , \\
\hline & pura & 5 \\
\hline & Mala & 9 \\
\hline & ysia & 3 , \\
\hline & Thail & 5 \\
\hline & and & 9 \\
\hline & India & 3 \\
\hline & Filipi & 2 \\
\hline & na & 8 \\
\hline & Vietn & 8 \\
\hline & am & 9 \\
\hline & Indon & 6 \\
\hline & esia & 9, \\
\hline & Kamb & 7 \\
\hline & odia & 6 \\
\hline & & 4 \\
\hline & & 3 \\
\hline & & 5 \\
\hline & & , \\
\hline & & 4 \\
\hline & & 5 \\
\hline & & 6 \\
\hline & & 4 \\
\hline & & $\begin{array}{l}3 \\
4\end{array}$ \\
\hline & & 4 \\
\hline & & 1, \\
\hline & & 2 \\
\hline & & 1, \\
\hline & & 4 \\
\hline
\end{tabular}


Keterangan: * = data sekunder Maret 2006

Sumber: World Economic Forum (2006).

Menurut jenis kredit, dapat dilihat di Gambar 3 bahwa peranan kredit usaha jangka panjang untuk investasi terus menurun dari tahun ke tahun. Bila pada tahun 2000 porsi kredit investasi masih sekitar 24,27\% dari total kredit perbankan pada tahun tersebut, maka pada Oktober 2006 porsi kredit ini tinggal 18,79\%. Sebaliknya porsi kredit konsumsi yang masih 14,9 \% pada tahun 2000, pada Oktober 2006 telah meningkat menjadi $29,4 \%$. Sementara itu, kredit usaha jangka pendek untuk modal kerja tetap paling besar dan secara absolut volumenya terus bertambah setiap tahun. Semakin rendahnya porsi kredit investasi tentu bukan suatu hal yang baik bagi perbaikan atau pertumbuhan sektor riil. Mungkin untuk periode jangka pendek, pertumbuhan sektor riil bisa didorong hanya oleh kredit konsumsi (lewat efek konsumsi) dan kredit modal kerja. Namun untuk periode jangka panjang, tidak ada pilihan lain selain meningkatkan investasi, dan ini membutuhkan dana besar termasuk dari perbankan.

Memang, penyebab utama dari merosotnya peran perbankan di dalam pendanaan investasi di sektor riil (atau ekonomi pada umumnya) bisa bersumber dari dua pihak, pertama pihak perbankan, karena lebih suka memberi kredit konsumen daripada kredit usaha (investasi atau modal kerja), kedua pihak pengusaha, karena tidak banyak kegiatan investasi atau kegiatan produksi dibawah kapasitas terpasang sehingga tidak banyak permintaan terhadap kredit investasi atau modal kerja.

Terakhir ini memang terbukti pada saat krisis ekonomi 1997/98 pada saat banyak bank nasional hancur karena besarnya kredit macet, dan tentu banyak bank yang menjadi trauma dengan peristiwa tersebut yang membuat mereka menjadi sangat, atau bahkan terlalu berhati-hati.

\section{Gambar 3: Perkembangan Kredit} Menurut Jenis (Triliun dollar AS)

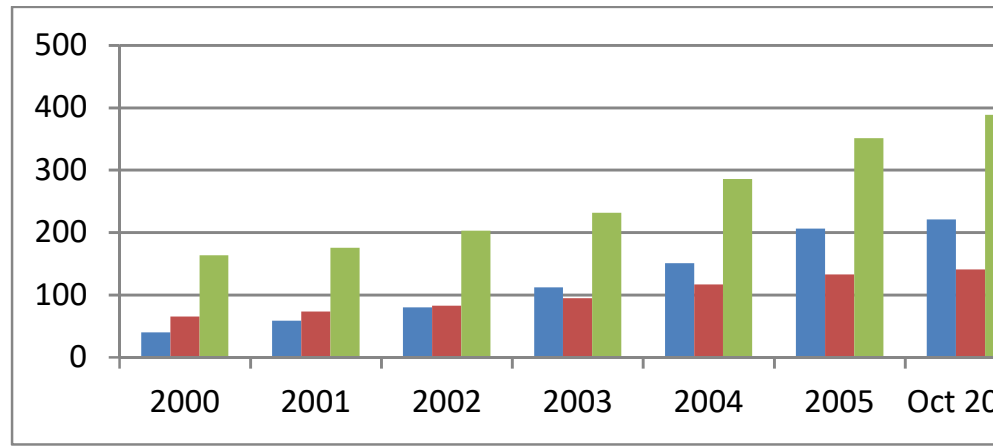

Sumber: Kadin Indonesia (data BI)

Berdasarkan uraian data-data di atas, terlihat sebuah fenomena yang ironis, bahwa di satu sisi upaya pemerintah untuk membesarkan Usaha Mikro Kecil dan Menengah (UMKM) begitu besar dengan upaya-upaya kebijakan yang pro-UMKM, akan tetapi dalam tataran implementasi hal itu tidak pernah sepenuhnya terwujud. Justru sebaliknya, kredit bagi UMKM semakin tidak sebanding dengan aturan tertulis kebijakan dan proporsionalitas dana yang bersarang di perbankan nasional sebagai satu-satunya lembaga intermediasi yang penting bagi kelangsungan UMKM. Hal ini ditunjukkan oleh tingkat kedudukan Indonesia yang masih selalu dalam level bawah dalam kualitas dan kuantitas penyaluran kredit kepada masyarakat apabila dibandingkan dengan negaranegara lain khususnya di Asia. Padahal, sebagaimana diuraikan pada awal sub-bab bab ini, Usaha Mikro Kecil Menengah (UMKM) merupakan motor penggerak perekonomian Indonesia yang menyentuh semua lini.

\section{b. Dilihat dari Sisi Perspektif Dunia Usaha/Pelaku UMKM}

Sedikitnya kredit yang disalurkan perbankan ke sektor riil selama ini bisa 
juga disebabkan oleh tidak adanya permintaan kredit dari dunia usaha. Hal ini bisa terjadi karena dua penyebab, pertama tidak ada pertumbuhan kegiatan ekonomi atau tidak ada rencana investasi yang besar sehingga membutuhkan dana pinjaman dari perbankan, atau kedua, pengusaha lebih suka mencari dana dari sumber-sumber alternatif seperti misalnya obligasi atau saham karena lebih menguntungkan atau karena di mata pengusaha sektor perbankan nasional belum baik, atau aksesnya sulit.

\section{b.1 Akses UMKM ke Kredit Perbankan}

Kurangnya kredit perbankan yang mengalir ke sektor riil selama ini bisa juga dikarenakan oleh sulitnya akses, dalam arti persyaratan terlalu ketat sehingga banyak pengusaha yang memilih sumber-sumber dana alternatif lainnya. Hal ini memang sangat masuk akal, karena di satu pihak, perbankan tidak mungkin secara terangterangan menutup pintu bagi dunia usaha yang ingin meminjam dana untuk investasi atau modal kerja. Namun perbankan punya keinginan, yakni lebih memilih menyalurkan kredit konsumen dan atau menanam di Sertifikat Bank Indonesia (SBI) atau Surat Utang Negara (SUN). Agar pilihan ini terpenuhi, maka perbankan memperketat syarat-syarat meminjam untuk maksud bisnis, apalagi investasi, sementara memperingan syarat-syarat meminjam untuk maksud konsumsi (misalnya untuk beli mobil atau rumah). Diskriminiasi dalam persyaratan kredit ini yang lebih berat ke dunia usaha bisa saja dilihat dari sudut pandang pengusaha sebagai terbatasnya akses ke kredit perbankan.

Seperti yang ditunjukkan di Tabel 5, Indonesia masuk di dalam 10 besar dengan skor 5.4. Untuk pertanyaan kedua tersebut, Tabel 6 menunjukkan kondisi yang sama, yakni mendapatkan kredit usaha menjadi lebih gampang dalam satu tahun terakhir. Posisi Indonesia juga masuk di dalam 10 besar. Lagi-lagi, sampel ini tidak mewakili pandangan dari seluruh pengusaha yang ada di Indonesia. Namun demikian, jika sebagian besar dari 135 pengusaha Indonesia yang menjawab dua pertanyaan tersebut beranggapan bahwa tidak ada masalah dengan akses ke perbankan, maka ini bisa menjadi suatu tanda bahwa memang demikian kenyataannya.

Tabel 5: Kemudahan Akses ke Kredit Perbankan dalam The Global Competitiveness Report 2006-2007*

\begin{tabular}{|c|l|c|}
\hline $\begin{array}{l}\text { Peri } \\
\text { ngka } \\
\text { t }\end{array}$ & $\begin{array}{l}\text { Nega } \\
\text { ra }\end{array}$ & $\begin{array}{c}\text { S } \\
\text { ko } \\
\text { r }\end{array}$ \\
\hline & Den & 5, \\
& mark & 6 \\
& Icela & 5, \\
& nd & 5 \\
1 & Inggr & 5, \\
2 & is & 5 \\
3 & Swe & 5, \\
4 & den & 4 \\
5 & Nor & 5, \\
6 & wegi & 4 \\
7 & a & 5, \\
8 & Indo & 4 \\
9 & nesia & 5, \\
10 & Bela & 3 \\
16 & nda & 5, \\
21 & Finla & 3 \\
23 & ndia & 5, \\
47 & UA & 2 \\
78 & Emir & 5, \\
87 & ates & 2 \\
99 & Irlan & 4, \\
113 & dia & 8 \\
& Sing & 4, \\
& apur & 6 \\
& a & 4, \\
& India & 5 \\
\hline & &
\end{tabular}




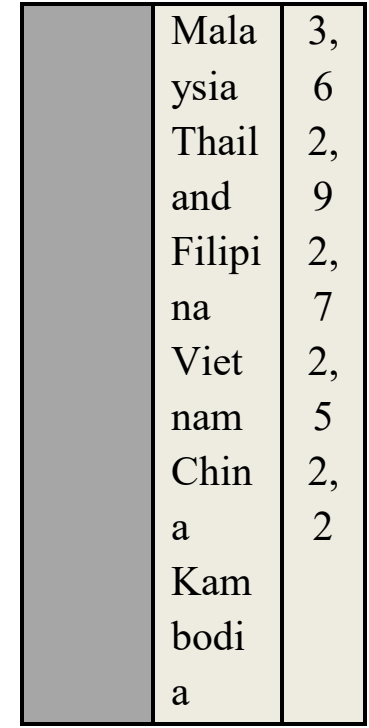

Keterangan: $*=$ data primer dari Executive Opinion Survey 2006. Sumber: World Economic Forum (2006).

Tabel 6: Akses ke Kredit Perbankan dalam Satu Tahun terakhir dalam The Global Competitiveness Report 2006$2007 *$

\begin{tabular}{|c|l|c|}
\hline $\begin{array}{l}\text { Peri } \\
\text { ngka } \\
\text { t }\end{array}$ & $\begin{array}{l}\text { Nega } \\
\text { ra }\end{array}$ & $\begin{array}{c}\text { S } \\
\text { ko } \\
\text { r }\end{array}$ \\
\hline & Irlan & 5, \\
dia & 9 \\
1 & Rep. & 5, \\
2 & Slov & 9 \\
3 & India & 5, \\
4 & Esto & 5, \\
5 & nia & 8 \\
6 & Den & 5, \\
& mark & 8 \\
& Swe & 5, \\
& den & 8 \\
\hline 7 & Turk & 5, \\
8 & i & 7 \\
9 & Taiw & 5, \\
10 & an, & 7 \\
31 & Chin & 5, \\
36 & a & 7 \\
40 & Icela & 5, \\
72 & nd & 7 \\
\hline
\end{tabular}

\begin{tabular}{|c|l|c|}
\hline 80 & Indo & 5, \\
85 & nesia & 1 \\
& Mala & 5, \\
& ysia & 0 \\
& Thail & 4, \\
and & 9 \\
& Sing & 4, \\
& apur & 5 \\
a & 4, \\
& Viet & 4 \\
& nam & 4, \\
& Filipi & 3 \\
& na & 3, \\
& Kam & 4 \\
& bodi & \\
a & \\
& Chin & \\
a & \\
\hline
\end{tabular}

Keterangan: $*=$ data primer dari Executive Opinion Survey 2006. Sumber: World Economic Forum (2006).

\section{b.2 Kondisi Perbankan Nasional}

Kurangnya kredit yang disalurkan ke dunia usaha di Indonesia selama ini sejak krisis ekonomi 1997/98 juga bisa disebabkan oleh kondisi perbankan nasional yang belum baik. Survei dari World Economic Forum (WEF) juga menanyakan masalah ini dari perspektif pelaku UMKM: "apakah menurut Anda kondisi perbankan di negara Anda baik?". Skor yang diberikan adalah antara 1 dan $7,1=$ buruk dalam arti solvabilitasnya rendah dan perlu bantuan dari pemerintah (seperti rekap yang dilakukan pemerintah Indonesia terhadap sejumlah besar bank nasional semasa krisis), dan 7 = sangat sehat dengan neraca yang sangat baik.

Hasilnya bisa dilihat di Tabel 7. Ternyata (seperti dugaan umum), sebagian besar dari 
pengusaha Indonesia yang menjawab pertanyaan tersebut menganggap bahwa kondisi perbankan nasional masih buruk, yang membuat Indonesia berada di peringkat ke 88 dan paling rendah di kelompok ASEAN setelah Vietnam dan Kambodia.

Tabel 7: Kondisi Perbankan Nasional dalam The Global Competitiveness Report 2006-2007*

\begin{tabular}{|c|l|c|}
\hline $\begin{array}{l}\text { Peri } \\
\text { ngk } \\
\text { at }\end{array}$ & $\begin{array}{l}\text { Nega } \\
\text { ra }\end{array}$ & $\begin{array}{c}\text { S } \\
\mathbf{k} \\
\text { or }\end{array}$ \\
\hline & Inggri & 6, \\
& s & 9 \\
& Swiss & 6, \\
& Denm & 9 \\
& ark & 6, \\
& Irland & 8 \\
1 & ia & 6, \\
2 & Kana & 8 \\
3 & da & 6, \\
4 & Luxe & 8 \\
5 & mbou & 6, \\
6 & rg & 7 \\
7 & Swed & 6, \\
8 & en & 7 \\
9 & Austr & 6, \\
10 & alia & 7 \\
21 & Belan & 6, \\
37 & da & 7 \\
43 & Belgi & 6, \\
75 & a & 6 \\
80 & Singa & 6, \\
88 & pura & 5 \\
103 & India & 6, \\
115 & Mala & 0 \\
& ysia & 5, \\
& Thail & 9 \\
& and & 5, \\
& Filipi & 2 \\
& na & 5, \\
Indon & 2 \\
\hline
\end{tabular}

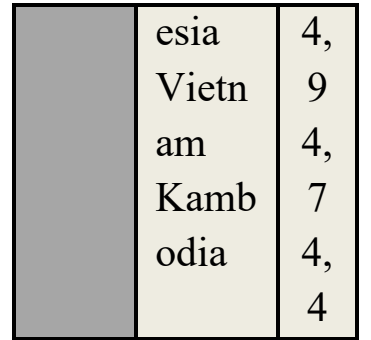

Keterangan: * = data primer dari Executive Opinion Survey 2006. Sumber: World Economic Forum (2006).

Hasil di Tabel 4 (ekspektasi resesi) dan hasil di Tabel 7 (kondisi perbankan) konsisten dengan laporan dari Standard and Poor 2006, mengenai resiko ekonomi dan perbankan di dunia menurut negara. Penilaiannya dibagi ke dalam 6 (enam) kategori: rendah, rendah sedang, sedang, tinggi sedang, tinggi, dan sangat tinggi. Menurut laporan tersebut, Indonesia bersama-sama dengan Filipina masuk ke dalam kategori tinggi untuk kedua bidang tersebut. Sebagai perbandingan, China dapat penilaian resiko tinggi untuk perbankan dan tinggi sedang untuk ekonomi, sedangkan India dan Thailand masuk kategori tinggi sedang untuk ekonomi dan perbankan.

Buruknya kondisi perbankan Indonesia disebabkan oleh kurangnya perhatian perbankan terhadap dunia usaha/pelaku UMKM. Hal ini diakibatkan oleh kecenderungan perbankan atas pembelian dan penerbitan investasi tidak langsung (jangka pendek) sebagaimana telah dijelaskan pada penjelasan di atas.

\section{c. Realisasi Kebijakan Perbankan}

\section{Terkini}

Perkembangan perbankan sepanjang tahun 2010 menunjukkan adanya recovery setelah krisis global yang berlangsung pada medio 2008. Hal tersebut tercermin dengan adanya pertumbuhan aset, kredit dan dana pihak ketiga (DPK) perbankan pada 
periode Juni hingga Desember 2009 yang relatif lebih tinggi dibanding semester pertama 2009.

Sepanjang 2009, pertumbuhan aset perbankan mencapai Rp 223 Triliun atau bertumbuh hampir sebesar $10 \%$ yang didorong oleh pertumbuhan kredit yang juga mencapai $10 \%$ atau sebesar $\mathrm{Rp} 130$ Triliun. Pertumbuhan kredit tersebut masih belum menunjukkan meningkatnya fungsi intermediasi perbankan yang optimal. Rendahnya pertumbuhan kredit di satu sisi disebabkan persepsi perbankan terhadap tingginya risiko sektor riil yang masih terimbas krisis keuangan global. Sebaliknya di sisi lain juga disebabkan aktivitas ekonomi yang melambat serta tingginya suku bunga. Loan to Deposit Ratio (LDR) ${ }^{52}$ yang merupakan salah satu indikator intermediasi perbankan, pada 2009 menunjukkan peningkatan rasio yang melambat setelah pada tiga tahun sebelumnya menunjukkan peningkatan yang relatif baik. Loan to Deposit Ratio (LDR) sepanjang 2005-2008 terus mengalami peningkatan, namun pada 2009 Loan to Deposit Ratio (LDR) mengalami penurunan dari $74,6 \%$ pada 2008 menjadi $72,9 \%$ pada Desember 2009. ${ }^{53}$

Walaupun penyaluran kredit tetap mengalami peningkatan pada 2009, akan tetapi kredit modal kerja mengalami penurunan jika dibandingkan 2008. Kondisi tersebut antara lain dapat disebabkan penerapan suku bunga perbankan yang tetap tinggi (suku bunga kredit rata-rata hanya turun sebesar kurang dari 100 basis poin) walaupun Bank Indonesia telah

52 Loan to Deposit Ratio (LDR) adalah indikator kemampuan perbankan dalam membayar semua dana.

53 Statistik Perbankan Indonesia (SPI), Bank Indonesia. menurunkan BI rate sepanjang tahun 2009 sebesar 275 basis poin.

Kondisi tersebut dikhawatirkan akan membuat terjadinya keengganan sektor riil dalam menggunakan fasilitas kredit untuk mendukung pengembangan perusahaannya. Keengganan penggunaan kredit tersebut juga tercermin dari undisbursed loan ${ }^{54}$ perbankan yang menunjukkan peningkatan sepanjang tahun 2008 hingga 2009. Porsi perbandingan undisbursed loan dengan kredit pada 2009 mencapai $22,5 \%$ yang merupakan rasio tertinggi sejak 2005.

Dari sisi dana pihak ketiga (DPK), pertumbuhan dana masyarakat sepanjang 2009 juga kurang menunjukkan peningkatan yang tinggi jika dibandingkan tahun-tahun sebelumnya. Sepanjang tahun 2009, peningkatan dana pihak ketiga (DPK) hanya sebesar Rp 220 triliun atau rata-rata meningkat sebesar Rp 18 triliun per bulan. Kondisi tersebut menurun jika dibandingkan rata-rata peningkatan dana pihak ketiga (DPK) per bulan di tahun 2008 sebesar Rp 20 triliun dan Rp 19 triliun di tahun 2007. Di masa yang akan datang, dengan membaiknya kondisi pasar finansial di luar perbankan, diperkirakan akan berat bagi perbankan untuk meningkatkan kepercayaan masyarakat agar tetap menyimpan dananya di bank. Diperlukan strategi yang inovatif bagi perbankan dalam usahanya meningkatkan dana pihak ketiga (DPK) khususnya dana yang memiliki biaya yang rendah (dana tabungan dan giro).

Dilihat dari komposisi dana pihak ketiga (DPK) yang ada, dimana porsi deposito masih memiliki share yang cukup besar (pada 2008 share deposito mencapai 47\%

\footnotetext{
54 Undisbursed Loan adalah kredit yang belum tersalurkan oleh perbankan.
} 
dan pada 2009 sebesar 46\%) membuat kemampuan perbankan untuk menekan biaya dana menjadi terbatas, yang pada akhirnya akan berdampak pada penurunan suku bunga kredit menjadi kurang optimal. Kondisi tersebut yang antara lain dapat melemahkan fungsi intermediasi perbankan terhadap sektor riil.

Tabel 1. Beberapa Rasio

Perbankan Nasional 2005-2009

\begin{tabular}{|c|c|c|c|c|c|c|}
\hline $\begin{array}{c}\text { Rasio } \\
(\%)\end{array}$ & $\begin{array}{c}200 \\
5\end{array}$ & $\begin{array}{c}200 \\
6\end{array}$ & $\begin{array}{c}200 \\
7\end{array}$ & $\begin{array}{c}200 \\
8\end{array}$ & $\begin{array}{c}\text { No } \\
\text { v } \\
200 \\
9\end{array}$ & $\begin{array}{c}\text { De } \\
\text { s } \\
200 \\
9\end{array}$ \\
\hline ВОРО & $\begin{array}{r}89 . \\
50\end{array}$ & $\begin{array}{r}86 . \\
98\end{array}$ & $\begin{array}{r}84 . \\
05\end{array}$ & $\begin{array}{r}88 . \\
59\end{array}$ & $\begin{array}{r}86 . \\
55\end{array}$ & $\begin{array}{r}86 . \\
63\end{array}$ \\
\hline ROA & $\begin{array}{r}2.5 \\
5\end{array}$ & $\begin{array}{r}2.6 \\
4\end{array}$ & $\begin{array}{r}2.7 \\
8\end{array}$ & 2.3 & $\begin{array}{r}2.6 \\
1\end{array}$ & $\begin{array}{r}2.6 \\
0\end{array}$ \\
\hline NIM ${ }^{55}$ & $\begin{array}{r}5.6 \\
3\end{array}$ & $\begin{array}{r}5.8 \\
0\end{array}$ & $\begin{array}{r}5.7 \\
0\end{array}$ & 5.6 & 5.5 & $\begin{array}{r}5.5 \\
6\end{array}$ \\
\hline NPL & $\begin{array}{r}7.5 \\
6\end{array}$ & $\begin{array}{r}6.0 \\
7\end{array}$ & $\begin{array}{r}4.0 \\
7\end{array}$ & 3.2 & $\begin{array}{r}3.8 \\
2\end{array}$ & $\begin{array}{r}3.3 \\
1\end{array}$ \\
\hline LDR & $\begin{array}{r}59 . \\
64\end{array}$ & $\begin{array}{r}61 . \\
56\end{array}$ & $\begin{array}{r}66 . \\
32\end{array}$ & $\begin{array}{r}74 . \\
58\end{array}$ & $\begin{array}{r}73 . \\
67\end{array}$ & $\begin{array}{r}72 . \\
88\end{array}$ \\
\hline CAR & $\begin{array}{r}19 . \\
30\end{array}$ & $\begin{array}{c}21 . \\
27\end{array}$ & $\begin{array}{r}19 . \\
30\end{array}$ & $\begin{array}{r}16 . \\
78\end{array}$ & $\begin{array}{r}17 . \\
08\end{array}$ & $\begin{array}{r}17 . \\
42\end{array}$ \\
\hline $\begin{array}{l}\text { SBI } / \mathbf{K r} \\
\text { edit }\end{array}$ & $\begin{array}{r}7.8 \\
0\end{array}$ & $\begin{array}{r}22 . \\
60\end{array}$ & $\begin{array}{r}20 . \\
35\end{array}$ & $\begin{array}{r}12 . \\
73\end{array}$ & 14. & $\begin{array}{r}14 . \\
75\end{array}$ \\
\hline
\end{tabular}

Sumber : Statistik Perbankan Indonesia (SPI), Bank Indonesia (BI)

Walaupun demikian, beberapa rasio kinerja perbankan mengalami peningkatan. Biaya Operasional terhadap Pendapatan Operasional $\left(\mathrm{BOPO}^{56}\right)$ yang merupakan salah satu indikator efisiensi menunjukkan

${ }^{55}$ Net Interest Margin (NIM) adalah indicator yang menunjukkan kemampuan bank dalam menghasilkan pendapatan dari bunga dengan melihat kinerja bank dalam menjalankan kredit.

56 Biaya Operasional terhadap Pendapatan Operasional (BOPO) adalah indikator yang menunjukkan efisiensi bank dalam menjalankan usaha pokoknya, yaitu dalam pengumpulan dana terutama dana masyarakat, perbaikan dan Return On Asset $\left(\mathrm{ROA}^{57}\right)$ juga mengalami peningkatan yang menunjukkan perbaikan kinerja perbankan yang relatif meningkat. Permodalan perbankan juga menunjukkan perbaikan yaitu dengan meningkatnya Capital Adequacy Ratio $\left(\mathrm{CAR}^{58}\right.$ ) menjadi 17,4\% walaupun belum dapat menyamai pencapaian di tahun 2006 sebesar 21,3\%.

Di samping rasio yang membaik, beberapa indikator menunjukkan adanya penurunan kinerja, di antaranya adalah LDR yang menurun dan Non Performing Loan $\left(\mathrm{NPL}^{59}\right)$ yang relatif mengalami kenaikan. Penurunan kualitas kredit tersebut mempengaruhi perbankan dalam penempatan dana yang dimilikinya. Hal tersebut dapat tercermin dari rasio penempatan Sertifikat Bank Indonesia (SBI) dibandingkan penyaluran kredit yang mengalami peningkatan pada 2009 menjadi sebesar 14,75\%, dibandingkan 12,73\% pada akhir 2008 .

Di samping itu, foreign portofolio investment juga mengalami perkembangan yang signifikan apabila dibandingkan dengan investasi untuk sektor riil (UMKM) sebagaimana telah dijelaskan sebelumnya. Perkembangan foreign portofolio investment berdasarkan Kementerian Keuangan telah mencapai $64 \%$ pada akhir 2010. Adapun perkembangan signifikan Surat Berharga Negara (Obligasi Negara)

${ }^{57}$ Return on Asset (ROA) adalah pengembalian atas total aktiva atau rasio laba bersih terhadap total aktiva.

58 Capital Adequacy Ratio (CAR) adalah indikator yang mencerminkan kecukupan modal bank, semakin tinggi CAR berarti semakin tinggi modal sendiri untuk mendanai aktiva produktif.

59 Non-Performing Loan (NPL) adalah rasio pinjaman yang bermasalah terhadap total pinjamannya. Semakin tinggi NPL semakin tinggi pula kredit macet sehingga berpotensi menurunkan perubahan laba. 
daripada dana untuk UMKM oleh perbankan adalah sebagai berikut:

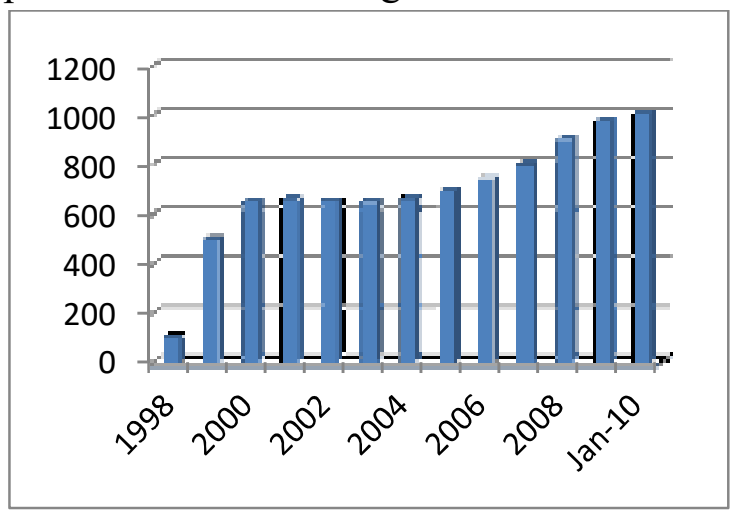

Sumber: Direktorat Jenderal Pengelolaan Utang Kementrian Keuangan Republik Indonesia

\section{Implikasi Globalisasi Keuangan terhadap Kebijakan Perbankan dalam Pemberian Kredit UMKM}

Sebagai bagian dari sebuah negara yang hidup dalam percaturan globalisasi, dunia telah terintegrasi tanpa pembatas yang jelas antara ruang dan waktu. Baik negara maju maupun negaranegara berkembang telah terintegrasi bersama-sama seolah-olah dunia adalah satu. Globalisasi telah menjelma dalam kluster-kluster yang bervariatif, termasuk globalisasi keuangan (foreign portofolio investment).

Globalisasi keuangan (foreign portofolio investment) telah mempengaruhi banyak negara-negara di dunia, khususnya negara-negara berkembang yang masih membutuhkan banyak bantuan dari negaranegara maju, termasuk Indonesia. Masuknya globalisasi keuangan telah melegalkan negara-negara lain untuk melakukan intervensi bisnis maupun politik, misalnya terhadap perbankan nasional Indonesia. Kebijakan pada masa pemerintahan Megawati Soekarno Putri hingga Susilo Bambang Yudhoyono merupakan penerus sejati kepemerintahan sebelumnya, sehingga liberalisasi perbankan pada masa Habibie terus berlanjut.

Kebijakan ini secara eksplisit telah mengatur legalisasi asing untuk menjalin kemitraan dengan tanpa batasan apapun. Hal ini dijelaskan dalam pasal 22 UU RI Nomor 10 tahun 1998 yang berbunyi : "Kepemilikan Bank Umum hanya dapat didirikan oleh warga negara Indonesia dan atau badan hukum Indonesia dengan warga negara asing dan atau badan hukum asing secara kemitraan”. Dengan UU ini, maka terbuka lebar globalisasi masuk dalam ranah politik, dengan kenyataan bahwa bank-bank Indonesia telah dikuasai oleh asing, dengan indikasi kepemilikan saham hampir rata-rata sebagian besar $50 \%$ lebih.

Fenomena di atas telah berimplikasi terhadap orientasi bank-bank nasional yang melenceng dari fungsi utamanya. Setidaknya telah terjadi 2 (dua) implikasi atas globalisasi keuangan terhadap perbankan, yaitu pertama implikasi terhadap legislasi UU Perbankan yang telah dipengaruhi asing melalui moral hazard aktor-aktor yang terkait karena mendatangkan self interest, kedua aktivitas perbankan cenderung ke kredit konsumsi dan kartu kredit apabila dibandingkan dengan penyaluran kredit ke UMKM.

\section{Alternatif Kebijakan dalam Upaya Pengembalian Fungsi Vital Perbankan Nasional \\ Pengembalian fungsi vital perbankan tentu bukanlah misi yang mudah untuk direalisasikan oleh perbankan nasional (Bank Indonesia), ditengah-tengah beratnya beban mengemban amanat "inflation}


targeting" di era tingginya inflasi global akibat tingginya harga minyak dan hargaharga komoditas. Dalam mendorong sistem keuangan yang sehat dan stabil, tentu saja regulasi dan supervisi perbankan harus dapat diperkuat untuk dapat meredakan "shock", serta mengambil keuntungan dalam era globalisasi yang makin tidak terkendali. Dalam konteks ini, tentu pengawasan yang ketat (heavily regulated) dan bukan "financial repression" yang perlu untuk dilakukan, sejalan dengan perbaikkan juga dalam fungsi vital perbankan, yakni "intermediasi".

Ada beberapa pilihan kebijakan yang dapat dilakukan untuk mengembalikkan fungsi vital intermediasi perbankan, atau menyelematkan perbankan dari kelumpuhan, antara lain: a) Kontrol Modal dan Regulasi ketat dalam aliran modal jangka pendek, b) Pengembangan penyedia informasi kredit (credit bureau), c) Pengembangan implementasi Manajemen Resiko yang terintegrasi, d) Penguatan modal sebagai buffer transaksi derivatif, e) Regulasi bagi masuknya bank asing di domestik dan f) Pengembangan perbankan syariah. Pilihan kebijakan diatas tentu memiliki nafas bahwa dengan semakin terintegrasinya pasar keuangan (perbankan) domestik dengan pasar keuangan internasional, maka kebutuhan untuk meregulasi dan melakukan supervisi yang baik menjadi kebutuhan yang sangat urgent. Jika merecall kembali apa yang dijelaskan oleh Stevens, bahwa krisis keuangan yang terjadi di sebagian besar negara berkembang disebabkan karena permasalahan di sektor perbankan. Hal ini tentu saja disebabkan karena pengaruh dan peran perbankan masih sangat dominan di negara berkembang yang notabene masih belum maju pasar keuangan pendukungnya. ${ }^{60}$

Pertama, pilihan kebijakan yang berkaitan dengan restriksi terhadap aliran modal "jangka pendek" atau yang dikenal dengan "hot money". Tentu saja, oppurtunity cost atau biaya pengorbanan secara ekonomis dari restriksi yang tinggi terhadap jenis modal ini adalah rendahnya ketersediaan modal bagi kebutuhan kredit domestik. Namun, pengalaman empiris menyebutkan bahwa aliran modal ini sangat rentan terhadap sentimen negatif yang pada akhirnya menyebabkan instabilitas pada perekonomian secara makro. Khususnya dalam memberikkan shock yang cukup berat terhadap stabilitas nilai tukar domestik. Krisis nilai tukar, yang telah meluas menjadi krisis keuangan, perbankan dan ekonomi di Asia merupakan contoh konkrit bahaya laten jenis modal ini. Dalam kaitannya dengan penguatan fungsi vital perbankan "intermediasi", pilihan kebijakan ini menjadi obat mujarab untuk membatasi pinjaman luar negeri bank yang berlebihan atau "international overborrowing", sehingga keterbukaan resiko keuangan (resiko kredit dan resiko nilai tukar) akan semakin terkendali. Sehingga pada akhirnya, stabilitas keuangan domestik juga akan semakin terjaga.

Kedua, pilihan kebijakan yang berkaitan dengan penyedia informasi kredit (credit bureau). Peningkatan resiko kredit macet, yang didominasi oleh kredit rumah tangga atau konsumsi menunjukkan lemahnya sistem pengawasan, monitoring dan pengujian kelayakan nasabah. Hal ini tentu disebabkan karena keterbatasan bank dalam mengakses secara lebih detail riwayat

60 Stevens, 'The Asian Crisis: a Restrospective', RBA Bulletin July 2007, hlm. 13. 
keuangan calon nasabah. Disisi lain, analisis arm-length yang dipaparkan sebelumnya, juga berkontribusi dalam lemahnya sistem manajemen resiko kredit perbankan saat ini. Oleh karena itu, kebutuhan akan penyedia informasi kredit yang berfungsi sebagai data base penyedia informasi bagi bank, menjadi sangat penting untuk direalisasikan. Hal ini selain akan mendorong biaya yang semakin rendah karena skala ekonomis yang tinggi, juga akan mengurangi terjadinya default atau resiko yang meningkat. Disisi lain, pilihan kebijakan ini akan mengurangi constraint kredit karena sektor perbankan akan lebih percaya atas keabsahan informasi dari penyedia kredit. Hal inilah yang pada akhirnya dapat meningkatkan fungsi intermediasi perbankan, karena semakin tingginya jumlah kredit yang berkualitas.

Ketiga, pilihan kebijakan yang berkaitan dengan implementasi kebijakan manajemen resiko. Pengaruh globalisasi keuangan yang semakin tinggi, dengan ancamannya yang menghadang, tentu saja membutuhkan perlindungan internal atau "manajemen resiko" yang kuat. Selain itu, semakin bervariasinya jenis investasi aset yang berkembang seiring dengan inovasi keuangan dan teknologi, mendorong penerapan manajemen resiko yang terintegratif. Dalam konteks ini, implementasi manajemen resiko perlu dilakukkan dalam berbagai aspek yang komplit, menyangkut sisi aset, liabilitas, manajemen dan lingkungan.

Keempat, pilihan kebijakan yang berkaitan dengan penguatan modal (capital as a buffer). Dengan semakin tingginya transaksi beresiko yang dilakukkan oleh perbankan, maka biaya atau cost yang harus dibebankan pada bank seharusnya juga meningkat. Dalam konteks ini, pembatas aktivitas perbankan ke arah transaksi yang beresiko harus dilakukkan dengan regulasi modal yang makin kuat. Hal ini bisa dilakukkan dengan memberikkan bobot modal yang tinggi untuk transaksi-transaksi beresiko tinggi. Sehingga dengan upaya ini, keinginan bank untuk meningkatkan aktivitasnya pada transaksi beresiko tinggi akan semakin terhambat, dan insentif untuk melakukkan penetrasi kredit yang produktif akan semakin meningkat.

Kelima, pilihan kebijakan yang berkaitan dengan masuknya bank asing di pasar keuangan domestik. Nafas untuk meningkatkan efisiensi yang dapat menurunkan biaya modal dengan hadirnya pemain asing yang masuk dalam industri perbankan, harus segera diklarifikasi dengan hati-hati. Meski terjadi dua polar pandangan seperti yang dipaparkan dalam landasan teoritis, berkaitan dengan masuknya bank asing dalam industri perbankan, maka diperlukkan analisis yang lebih country specific untuk menjawab "Apakah masuknya bank asing menjadi sumber instabilitas keuangan yang menganggu perekonomian domestik?". Dalam konteks ini, penulis lebih berhatihati untuk menilai masuknya bank asing dalam pasar domestik. Hal utama yang mendasarinya adalah, berdasarkan data BI yang telah dipublikasikan, ROA bank umum domestik tidak meningkat secara signifikan dalam waktu terakhir. Meski banyak faktor yang mendasarinya, namun jelas terungkap bahwa perbaikan efisiensi dalam industri perbankan tidak terpengaruh dengan masuknya bank asing di dalam indutri perbankan tanah air. Di sisi lain, aktivitas perbankan asing yang lebih menyukai penetrasi kredit di sektor konsumsi dan menghindari pembiayan dunia usaha yang produktif, sesungguhnya 
merupakan ancaman eksploitasi pasar keuangan saja. Dengan kata lain, fungsi intermediasi yang produktif dari institusi ini masih belum dapat dirasakan secara maksimal di pasar keuangan domestik.

Terakhir, pilihan kebijakan yang berkaitan dengan pengembangan bank syariah. Pengembangan bank syariah pada dasarnya memiliki visi kedepan dalam pembangunan. Hal ini disebabkan karena hubungan "relational" memiliki kekuatan secara kelembagaan dalam industri perbankan syariah. Selanjutnya beberapa skim pembiayaan yang produktif, yang dimiliki oleh perbankan syariah patut diakui bahwa institusi ini mampu memberikkan fungsi intermediasi yang optimal bagi pengembangan pasar keuangan domestik. Suatu hal yang sangat berharga yang diajarkan dalam syariah economics bahwa spekulasi atau gharar sangat dilarang. Dan, uang sebagai alat tukar harus dikembalikan pada fungsi dasarnya sedia kala. Oleh karena itu perilaku-perilaku yang memperjualbelikan uang (menganggap uang sebagai komoditas) pada akhirnya hanya mendorong terjadinya krisis keuangan dan krisis ekonomi. Hal inilah yang seharusnya dijunjung tinggi dalam sistem keuangan domestik, bahwa perbankan harus kembali dari kelumpuhan "intermediasi" akibat kemajuan yang dialaminya sendiri. Dengan kata lain, perbankan akan terbebas dari kemajuan yang membawa kemunduran.

Kebijakan-kebijakan ini tentu saja memerlukan intervensi politik pemerintah yang kompeten sebagai manager aktivitas ekonomi negara, agar tidak terjebak dalam kegagalan pemerintah (government failure), sehingga peran pemerintah secara politik berperan besar dalam mengontrol dan mengendalikan kegiatan ekonomi yang berlangsung pada kebijakan-kebijakan yang menyangkut publik, tidak terkecuali kebijakan yang menyangkut foreign portofolio investment ini. Jika tanpa syarat itu, maka tindakan ekonomi politik pemerintah akan berpotensi gagal atau menambah problem baru dan menimbulkan ketidakstabilan pada pasar secara keseluruhan. 


\section{Kesimpulan}

Kebijakan pemerintah dalam
pengembangan UMKM yang paling
penting adalah dalam bidang bantuan
finansial. Hal ini mengingat masalah
finansial dalam masalah pemodalan atau
pembiayaan merupakan salah satu masalah
sulit yang dihadapi oleh para pelaku
UMKM di Indonesia. Sebagian besar
UMKM di Indonesia memenuhi kebutuhan pembiayaannya dengan mengandalkan uang pribadi yang berasal dari tabungan, pinjaman dari saudara atau teman, atu meminjam dari rentenir. Sumber-sumber pembiayaan tersebut umumnya tidak dapat diandalkan keberlangsungannya, di samping memberatkan. Sedangkan untuk menarik pinjaman dari institusi keuangan formal seperti bank, kebanyakan UMKM masih belum bisa memenuhi persyaratan yang ditetapkan, khususnya dalam penyediaan jaminan (kolateral). Oleh karena, perlu ada campur tangan pemerintah secara politik guna membantu UMKM mengatasi kesulitan finansialnya.

Untuk memenuhi kebutuhan pembiayaannya, terutama untuk modal kerja, UMKM banyak menggantungkan pada bantuan pemerintah dan berbagai lembaga keuangan formal maupun nonformal seperti perbankan, non-perbankan, modal ventura, pelepas uang, dan dari pihak-pihak swasta lainnya

Kebijakan liberalisasi foreign portofolio investment, sebagai aktivitas ekonomi yang liberal, akan berakibat aktivitas ekonomi yang tidak terkontrol, apabila tidak diikuti dengan aktivitas politik yang kuat. Perbankan sebagai lembaga yang potensial melakukan aktivitas pembelian maupun penerbitan foreign portofolio investment sangat rentan terhadap aktivitas ekonomi yang tidak terkontrol, sehingga penyelewengan fungsi utama intermediasi dapat terabaikan tanpa aktivitas politik yang kuat. Aktivitas liberalisasi foreign portofolio investment berpengaruh terhadap fungsi vital/utama perbankan dalam pemberian kredit kepada Usaha Mikro Kecil Menengah (UMKM).

Rendahnya akses pemberian kredit kepada UMKM, lebih dikarenakan perbankan lebih suka melakukan aktivitas bisnis (ekonomi) dalam rangka untuk memperoleh keuntungan yang lebih besar dan cepat melalui instrument investasi portofolio. Oleh karena itu, dalam mengatasi masalah bisnis (ekonomi) tersebut, maka yang dibutuhkan adalah pemerintah sebagai manajer yang kompeten (competent manajer). Jika tanpa syarat itu, maka tindakan ekonomi politik pemerintah akan berpotensi gagal atau menambah problem baru dan menimbulkan ketidakstabilan pada pasar secara keseluruhan.

Di sini intervensi pemerintah merupakan peluang yang bagus untuk menciptakan stabilitas ekonomi, namun hal itu juga tidak mudah dijalankan karena kegiatan ekonomi merupakan multifaset yang sulit ditebak alirannya. Oleh karena itu, agar intervensi pemerintah tidak terjebak menjadi "kegagalan pemerintah", maka pemerintah yang kompeten sangat dibutuhkan. Peran pemerintah secara politik berperan besar dalam mengontrol dan mengendalikan kegiatan ekonomi yang berlangsung pada kebijakan-kebijakan yang menyangkut publik. 


\section{Daftar Pustaka}

Joseph. E. Stiglitz, "Capital market

Liberalization economic Growth and Instability.

Mc Kinon. R and Huw Pill, "Exchange rate Regimes For Emeging Market', Moral Hazard and International Overborrowing", Oxford Review of Economic policy, 1999.

Sunaryati Hartono, "Beberapa Masalah Transnasional Dalam Penanaman Modal Asing di Indonesia, Penerbit Bina Cipta, Bandung, 1972.

Nindyo Pramono, "Sertifikasi Saham PT Go Public dan Hukum Pasar Modal di Indonesia, Penerbit PT Aditya Bakti, Bandung 2001.

Chung H, Lee, "Financial Liberalization and the Economic Crisis In Asia', University Of Hawaii At Manoa, East-West Center and European Institute Of Japanese Studies Stockholm School Of Economics.

Jonker Sihombing, "Infestasi Asing Melalui Surat Utang Negara di Pasar Modal, Bandung, PT. Alumni, 2008.

Schmukler, S. L., "Financial Globalization: Gain and Pain for Developing Countries," Federal Reserve Bank of Atlanta E c o n o m i c R e vi e w Second Quarter, 2004.

Umaran Mansyur, "Teknik Perdagangan Efek di Bursa Efek Indonesia”, Aksara Kencana, Jakarta, 1986.
Frank Fabozzi dan Franco Modigliani, "Capital Market, Institution, and Instrumen," Prentice Hall, New Jersey, 1996. 